\title{
The 1902-3 eruptions of the Soufrière, St Vincent: Impacts, relief and response
}

\author{
David M. Pyle ${ }^{\mathrm{a}, *}$, Jenni Barclay ${ }^{\mathrm{b}}$, Maria Teresa Armijos ${ }^{\mathrm{c}}$ \\ a Department of Earth Sciences, University of Oxford, South Parks Road, Oxford OX1 3AN, UK \\ b School of Environmental Sciences, University of East Anglia, Norwich NR4 7TJ, UK \\ c School of International Development, University of East Anglia, Norwich, NR4 7TJ, UK
}

\section{A R T I C L E I N F O}

Article history:

Received 15 November 2017

Received in revised form 8 March 2018

Accepted 11 March 2018

Available online 17 March 2018

\begin{abstract}
A B S T R A C T
Retrospective analysis of the contemporary colonial and scientific records of a major explosive eruption of the Soufrière of St Vincent from 1902 to 1903 reveals how this significant and prolonged event presented challenges to the authorities charged with managing the crisis and its aftermath. In a small-island setting vulnerable to multiple hazards, the spatial footprint of the volcanic hazard and the nature and intensity of the hazard effects were rather different to those of other recurrent hazards such as hurricanes. The eruption affected the same parts of the island that had been impacted by prior explosive eruptions in 1718 and 1812, and hurricanes in 1831 and 1898 , with consequences that disproportionately affected those working in and around the large sugar estates. The official response to the eruption, both in terms of short-term relief and remediation, was significantly accelerated by the existence of mature plans for land-reform following the collapse of the sugar market, and ongoing plans for rebuilding in the aftermath of the destructive hurricane of 1898. The picture that this analysis helps to illuminate provides insights both into the nature of the particular eruptive episode, and the human and social response to that episode. This not only informs discussion and planning for future explosive eruptions on St Vincent, but provides important empirical evidence for building effective responses in similar multihazard contexts.
\end{abstract}

(C) 2018 The Authors. Published by Elsevier B.V. This is an open access article under the CC BY license (http:// creativecommons.org/licenses/by/4.0/).

\section{Introduction}

St Vincent is a small volcanic island in the Eastern Caribbean. It lies in the southern part of the Lesser Antilles volcanic arc, which is a chain of 11 islands and at least 17 volcanoes that stretch from Grenada to Saba (Macdonald et al., 2000). Six volcanoes along the arc have erupted since 1900; most recently the Soufrière Hills Volcano on Montserrat (Wadge et al., 2014). Magmas that have erupted from the Soufrière of St Vincent during the Holocene include primitive arc basalts and mafic andesites that often carry a prominent plutonic inclusion suite. Experiments, modelling and petrological, geochemical and isotopic analysis have allowed petrologists to develop conceptual models for the origins and evolution of magmas beneath St Vincent (e.g. Arculus and Wills, 1980; Heath et al., 1998; Zellmer et al., 2005; Pichavant et al., 2002; Melekhova et al., 2015).

The island of St Vincent lies in the hurricane belt, and is susceptible to both strong windstorms and heavy rains. Two-thirds of the island is forested (FAO, 2010). In common with many small volcanic islands, the geography of St Vincent is dominated by the volcano, whose steep sides, poorly-consolidated bedrock and incised ravines (or 'gutters',

\footnotetext{
* Corresponding author.

E-mail address: david.pyle@earth.ox.ac.uk (D.M. Pyle).
}

Nanton, 2017) present a suite of ongoing hazards during periods of both quiescence and unrest (e.g. from sediment-charged flash floods and landslides).

On the Windward (eastern) side of St Vincent (Fig. 1), sediment supply from the foothills of the Soufrière has formed a broad coastal strip, the Grand Sable, that was exploited for sugar plantations from the late 18th Century. The Soufrière itself is not visible from the Windward side. On the Leeward (western) side of St Vincent, the deep valleys and rich soils are better suited to the small-scale cultivation of vegetables and fruit; while the Soufrière can be seen from many points north of Troumaca. This geography has strongly influenced the patterns of settlement and land-use in the past; and continues to place severe space constraints on future growth, and options for development (Wilkinson et al., 2016). One way to better understand volcanic risk in such settings, is to explore measures for risk reduction (whether through planning, communication or education; e.g. Barclay et al., 2008, 2015; Mani et al., 2016; Hicks et al., 2017). Another is to better understand the links between the physical, social and economic impacts of past hazard events; this is the focus of our paper.

Recent volcanic activity on St Vincent has been confined to the Soufrière volcano in the northern part of the island (Fig. 1; Anderson and Flett, 1903; Robertson, 1995). The summit of the Soufrière comprises a complex of intersecting craters of different ages, suggesting 


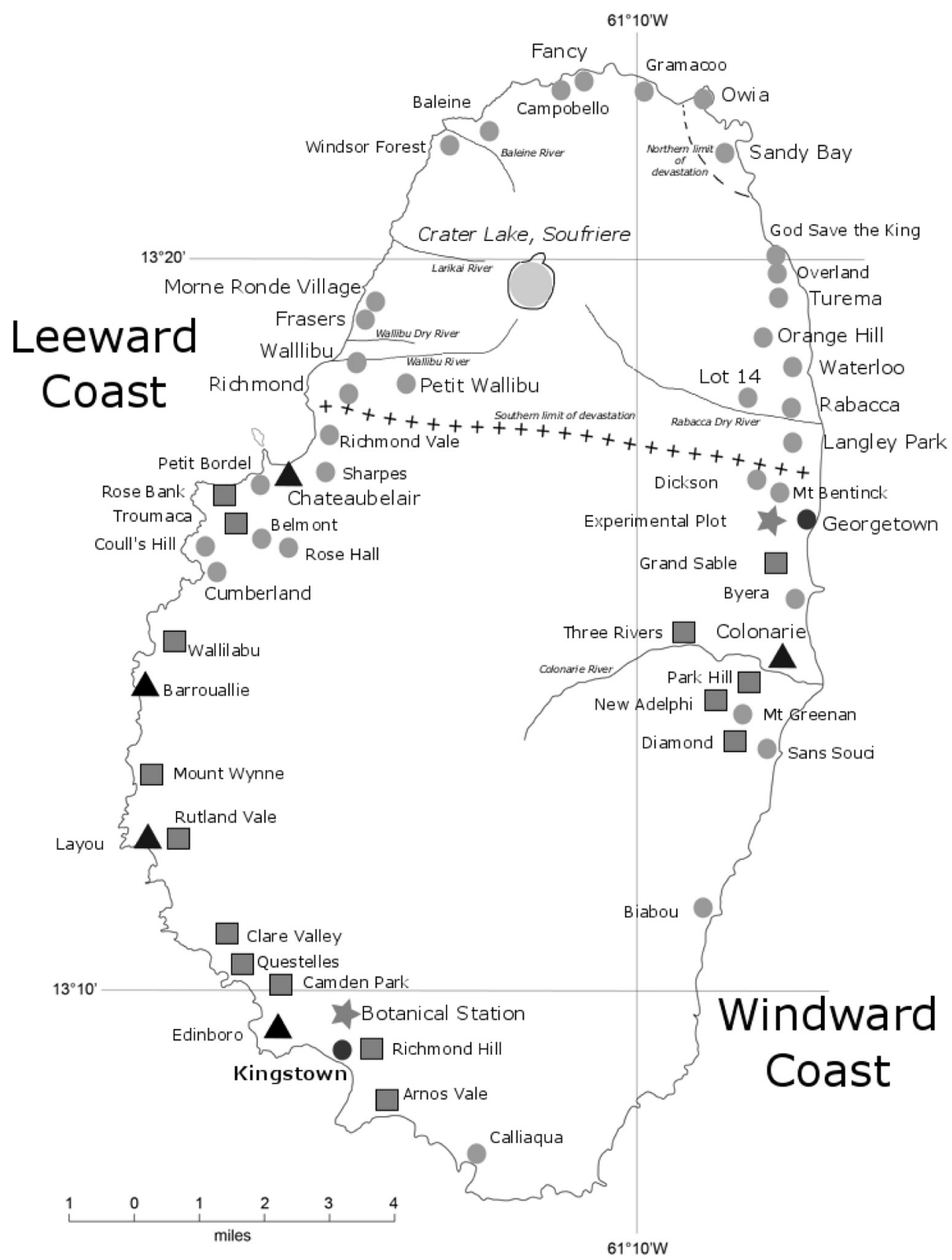

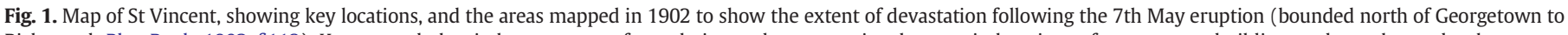

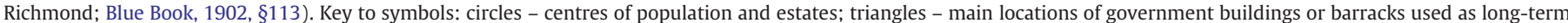

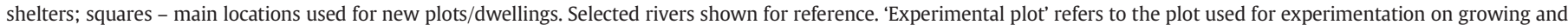
crops (see Fig. 4).

that it has experienced repeated eruptions during its history. While the longer eruption history is not well known, there have been at least 5 eruptions since 1718, which mean that St Vincent is - by this measure - the most active subaerial volcano in the Caribbean (Table 1). Eruptions over the past 300 years have occurred against the backdrop of an evolving social, economic and political environment. Several of these eruptions (notably those in 1812, 1902-3, 1971-2 and 1979) were well documented in contemporary official records and reports (see Table 1; Anderson and Flett, 1903; Robertson, 1995). However, there has been little later work published on either what happened during the eruptions, or on the physical, social and economic consequences of the eruptions, beyond an assessment of the hazards posed by the volcano (Robertson, 1995). The only exception, and the only eruption that has received any close retrospective analysis so far, is that of 1812 (Smith, 2011).

The eruptions of May 1902 to March 1903 were well documented in contemporary official (colonial) records. Work on these eruptions and the simultaneous eruptions of Mont Pelée, Martinique, by scientific deputations from the UK, US and France played an important role in advancing the science of volcanology, in particular in the recognition of 'nuée ardentes', or pyroclastic density currents, (e.g. Hovey, 1902; Anderson and Flett, 1903; Lacroix, 1904). However, since that time, there have been few attempts to draw together the very many pieces of documentary evidence to assess the wider consequences of this eruption for St Vincent and its inhabitants. Here, we present a synoptic analysis of the 1902-3 eruptions of St Vincent, and seek to draw some 
Table 1

A short chronology of natural hazard events on St Vincent, 1718-1903.

\begin{tabular}{|c|c|c|}
\hline Date & Volcanic or seismic event & Hydro-meteorological event \\
\hline $\begin{array}{l}26 \text { March } \\
1718\end{array}$ & $\begin{array}{l}\text { Explosive eruption, with ash } \\
\text { fallout across Barbados }{ }^{1,2}\end{array}$ & \\
\hline 1780 & Increased fumarolic activity ${ }^{2,3}$ & Hurricane $^{4}$ \\
\hline 1784 & $\begin{array}{l}\text { First documented visit to the } \\
\text { summit crater }^{5}\end{array}$ & \\
\hline 1811 & Strong earthquakes ${ }^{3}$ & \\
\hline \multirow{4}{*}{$\begin{array}{l}27 \text { April-6 } \\
\text { May } 1812\end{array}$} & Explosive eruption, with wide & \\
\hline & destruction in the north of St & \\
\hline & Vincent, and ash fallout across & \\
\hline & Barbados $^{2,6} .56$ fatalities ${ }^{2,7}$ & \\
\hline $\begin{array}{l}9 \text { January } \\
1814\end{array}$ & $\begin{array}{l}\text { Minor eruption or solfataric } \\
\text { activity }^{2}\end{array}$ & \\
\hline 1814 or 1815 & & $\begin{array}{l}\text { Flood, due to failure of a sand } \\
\text { and ash dam of the Wallibu river } \\
\text { which formed after the } 1812 \\
\text { eruption }{ }^{4}\end{array}$ \\
\hline $\begin{array}{l}23 \text { December } \\
1816\end{array}$ & Earthquake $^{4}$ & \\
\hline $\begin{array}{l}11 \text { August } \\
1831\end{array}$ & & Great Hurricane $^{4,8}$ \\
\hline 1880 & $\begin{array}{l}\text { Crater lake temperatures and } \\
\text { water levels rise; increased } \\
\text { fumarolic activity }^{2,3} \text {. }\end{array}$ & \\
\hline 11 & & Great Hurricane. 20,000 left \\
\hline $\begin{array}{l}\text { September } \\
1898\end{array}$ & & homeless; 300 deaths $^{9}$ \\
\hline $\begin{array}{c}\text { Feb- Mar } \\
1901\end{array}$ & $\begin{array}{l}\text { 'Numerous' earthquakes in the } \\
\text { north of the island, Feb-March } \\
1901 \text { (ref. 2). }\end{array}$ & \\
\hline $\begin{array}{l}20 \text { August } \\
1901\end{array}$ & & $\begin{array}{l}\text { Violent tropical storm caused } \\
\text { extensive damage to Kingstown } \\
\text { harbor }^{10} \text { and Leeward parts of } \\
\text { the island }^{11}\end{array}$ \\
\hline $\begin{array}{l}\text { 6-7 May } \\
1902\end{array}$ & $\begin{array}{l}\text { Major sequence of explosive } \\
\text { eruptions, began } 1 \text { pm, May } 6 \text {, }\end{array}$ & \\
\hline 18 May 1902 & 1902. & \\
\hline $3-4$ & Subsequent explosive phases & \\
\hline September & continued until March 23, 1903 & \\
\hline 1902 & (refs. 12,13) & \\
\hline $15-16$ & & \\
\hline October 1902 & & \\
\hline 22 March & & \\
\hline 1903 & & \\
\hline
\end{tabular}

Table compiled from a synthesis by Boruff (2006), with additional cross-references. Date precision reflects that described in the source material.

1 - Defoe (1718a); 2 - Anderson and Flett (1903); 3 - Robertson (1995); 4 - Shepherd (1831); 5 - Anderson (1785); 6 - Smith (2011); 7 - Huggins (1902); 8 - Smith (2012); 9 - Richardson, 1997; 10 - Colonial Reports, 1903a, 1903b); 11 - Adams (2002); 12 Blue Book (1902); 13 - Blue Book (1903).

general conclusions about the factors that influenced both the immediate consequences of this eruption, and also the longer-term recovery following the eruption. Our analysis reveals some of the particular consequences of extended and 'multi-hazard' events that may modify, or in some cases amplify, the environmental, social and economic consequences of a major hazard event.

\section{A brief chronology of volcanic eruptions and other events on St Vincent}

The earliest eruption of St Vincent for which there are any documentary records was that of March 1718, which was described in a contemporary English pamphlet (Defoe, 1718a; Pyle, 2018). At that time, St Vincent was inhabited by Caribs, and had not yet been settled by the French or British. Defoe's account of 'the destruction of the isle of St Vincent' was compiled from letters from passing sailors, and reports earthquakes, and the climactic phases of an explosive eruption, accompanied by detonations and lightning, and the fallout of ash as far afield as Barbados, Martinique and Venezuela. Defoe noted later that that the island of St Vincent was 'turn'd in to a Vulcano or burning mountain' (Defoe, 1718b).

In 1763, the French surrendered St Vincent and the Grenadines to the control of the British, under the treaty of Paris. The British colonists appointed a Governor, and commissioned John Byres to complete a survey of the island (Byres, 1777). This survey detailed the way that the island was divided into freehold and leasehold parcels of land, cultivable lands for sale as plantations, and lands allocated to the Caribs. Byres' survey map, and others subsequently, do not identify the Soufrière itself, referring instead to the northern belt of mountains as 'Morne Garou Mountain'. The first technical descriptions of an ascent of Morne Garou, and of a view into the active summit crater date from 1784. At this time the steep-walled crater contained two small lakes, and what we would now interpret as a steaming lava dome (Anderson, 1785). It is not known when this dome was extruded.

\subsection{Eruption of 1812}

By the early 1800 s, much of the fertile land along the windward side was cultivated for sugar-cane, in a small number of monocultural estates owned by British landlords, sustained by enslaved workers. In April 1812, there was a major explosive eruption. This was recorded in detail in diaries, newspapers and other accounts (e.g. Browne, 1813), and has been analysed in close detail by both Anderson and Flett (1903) and Smith (2011). A view of the eruption from Chateaubelair Bay was captured in a painting by JMW Turner, based on the sketches of the event by a local landowner and diarist, Hugh Perry Keane (Smith, 2011; see also Pyle, 2017).

Contemporary descriptions reveal the pattern of events: some precursory felt earthquakes in the north of the island were followed by three or four days of violently explosive eruptions from the 29th of April to the 1st of May with further brief eruptive activity on the 6th of May, accompanied by widespread ash fallout across St Vincent and Barbados. Both Windward and Leeward sides of the northern parts of the island were heavily affected by the eruption, including lahars, and thick ash fallout. The 1812 eruption seems to have had a single climactic phase, with a peak of activity over night on April 30th. Apart from a report of an explosion on 9th January 1814 (letter to a newspaper from 1880, quoted in Anderson and Flett, 1903) there is no evidence for any further eruptive activity at the volcano during the 19th Century. The lava dome was evidently destroyed during the eruption of 1812, and by the mid 1830s based on contemporary lithographs, the summit crater was entirely filled with water. Apart from a poorly-documented episode of unrest around 1880, it remained in this state until the eruption of 1902 (Table 1).

The main impacts of the 1812 eruption were confined to the northern half of the island. Here, there was a significant, but short-lived, impact on the infrastructure (primarily damage to plantations). Fifty six deaths were reported (Foster Huggins, 1902), although there are no details known of when, or how, these occurred. As Anderson and Flett (1903) noted, and Smith (2011) amplified, some of the contemporary reports of the immediate economic consequences of the eruption were exaggerated. Notably, the plantation owners petitioned the Crown arguing that they should be compensated for their losses, on account of their having only recently purchased the lands from the Crown, while being unaware that the island was a volcano (Browne, 1813). They were duly compensated, and within five year output of sugar and rum from the Windward plantations had doubled (Smith, 2011). Many estates incurred debts to facilitate the reconstruction that later contributed to their decline and abandonment (Spinelli, 1973). Smith (2011) estimates that the 1812 eruption led to a fall in output of $14 \%$ of GDP, and infrastructure damage at $7 \%$ of all of the physical capital invested in sugar estates. 


\subsection{Hurricane of 1831}

In August 1831, St Vincent was struck by a major hurricane. In contrast to the eruption of 1812, this event had an island-wide impact, with damage to property and crops across 92 of the 96 sugar estates active at the time, and an estimated mortality across the island of 50-100 (Smith, 2012). Disproportionate claims for compensation were received from estates within the 'Charlotte' parish that covers the north and northwest portions of the island; emphasising the susceptibility of populations here to both hydro-meteorological and geophysical hazards (Robertson, 1995; Boruff and Cutter, 2007; Smith, 2011). Sugar production across the island fell by $75 \%$ that year, but recovery was rapid, and sugar exports recovered within two growing seasons (Smith, 2012). Within three years, St Vincent society changed radically with the abolition of slavery, but the further debts shouldered by many estates as a consequence of this hurricane were felt for many decades.

\section{Social and economic change, 1812-1902}

Between 1812 and 1902, the population of St. Vincent increased from ca. 27,000 to 41,000 (Smith, 2011; Colonial Reports, 1903a), and there were significant changes in living circumstances for the majority of the population after slavery was abolished in 1834 . Traditionally, estate workers had been given land on which to grow their own food ('ground provisions'), usually somewhat removed from their living quarters. Following emancipation, many women elected to attend to these plots in preference to working on the estates, selling the excess produce at local markets, and enabling them to focus on childcare (Boa, 2001). Elective labourers on the monocultural estates were either indentured servants, tenants or free labourers resident elsewhere, with the latter receiving the highest wages. Free villages began to grow during this period, although the prohibitive costs of procuring and building on land meant that this was not widespread practice (e.g. Spinelli, 1973; Gearing, 1988). There was also off-island male emigration, driven by a desire to secure higher-paid work in order to save funds to secure free lands. Free villages and the growth of smallholders tended to happen on the margins of existing estates and in the productive lands in the south of the island (Gearing, 1988).

The decline of the European sugar market, driven by lower cost European beet, compounded by low wages, and poor living and working conditions on estates where the landowners were largely absent, also contributed to the decline of emancipated workers (Spinelli, 1973). After 1856, the Encumbered Estates Act forced the sale of bankrupt estates; while the immigration of indentured labourers from East India grew through the 1860s-1880s. One consequence of this was the increasing concentration of the ownership of cultivable lands in the hands of fewer and fewer owners. In 1829, there were 98 sugar estates on St Vincent. By 1848, just 12 of 100 estate owners lived on island. Sugar duty was abolished in 1874 , but by this stage sugar production on St. Vincent was in deep decline. By 1882, most of the cultivable land on the island was owned by five people; D.K. Porter \& Co. owned 22 estates, and two-thirds of the productive lands on the island, most of which was farmed by tenant labourers (Royal Commission, 1897; Nanton, 1983).

\subsection{Land settlement fund, 1897}

In December 1896, a Royal Commission was tasked to 'inquire into the conditions and prospects of the sugar-growing West Indian Colonies'. The Commissioners visited the West Indies in early 1897, and their report provides a wealth of documentary evidence as to the state of agricultural production (Royal Commission, 1897). At that time, sugar-cane products accounted for a considerable proportion of the exports from St Vincent. From 1890 to 1896, the value of sugar exports dropped from $£ 63 \mathrm{k}$ to $£ 24 \mathrm{k}$, and of total exports from $£ 103 \mathrm{k}$ to $£ 57 \mathrm{k}$, primarily due to the collapsing price for sugar imported to the UK, exacerbated by a fall in the price of arrowroot in 1896 (Royal Commission, 1897, $\S 261)$. The Commissioners reported that the island economy was in terminal decline and the majority of the population were enduring poverty. Sugar cane production was foundering because of poor landmanagement, pests, and poor processing and refining capacity (Royal Commission, 1897, §263). Arrowroot exports were suffering due both to a reduction in quality, and overproduction; and other economic crops (cacao, fruit, spices, cotton) were produced in only small quantities.

A more serious problem identified by the Commissioners was the overall distribution of land ownership on St Vincent. The Crown Lands, which covered much of the interior of the island, were in the process of being parceled up and sold as small-holdings, with the proviso that the landowner should plant at least half of the area with a permanent product (coffee, cacao, spices). However land-owners were generating little income from cultivation, and as their wages from the sugar estates dropped, they were falling into arrears with their payments of installments for the land. Disastrous floods in 1896 badly affected many of the new allotments (Royal Commission, 1897, §274). To compound matters, the Crown lands were poorly located, being remote from settlements and roads, and often on steep slopes and difficult to cultivate. The privately-owned sugar estates were little better off. Here were 'thousands of acres of unused land .. that possess a rich soil and within easy reach of habitations and accessible by existing roads and paths'. However, although the absentee landowners were not using the land for cultivation, they were also not willing to sell the land. The conclusions were stark: the sugar industry was facing extinction, and since 'there is no prospect of private enterprise establishing other industries on a sufficiently large scale ... the problem becomes one of extreme urgency' (Royal Commission, 1897, §373). The Commissioners recognized that the urgent need for land reform, and came up with a radical proposal, that led to the Land Settlement Act, that 'suitable portions of (private) lands be acquired by the State and made available for settlement in small plots. The condition of St Vincent is so critical as to justify the adoption of prompt and drastic measures of reform' (Royal Commission, 1897, $\S 377)$. The Commissioners recommended that the costs of these measures should be borne by the Imperial Government, and suggested also that efforts be made to diversify the production of economic crops on St Vincent, such as growing bananas for export to New York. This marked the start of what became the major cash crop for the Windward Islands in later parts of the 20th century (Grossman, 1998; John, 2006).

A 'Roads and Land Settlement Fund' was established to facilitate the process of reform, by acquiring estate lands. In 1898, the Colonial Office awarded a grant of $£ 15,000$ to begin the process; and the Land Settlement Ordinance was passed in January 1899. The Ordinance required that parts of the lands that were acquired should be reserved for 'townships, roads, public buildings, forest and stream conservation, etc.', and that all remaining lands be parceled up into 5 -acre allotments. Applicants for small holdings were expected to pay a $25 \%$ down payment for the land, and to pay off the balance, with interest, in twelve annual installments starting five years after purchase. After 16 years, they would own the land outright. Small holders were required to manage the land (clearing, planting, sales of produce) according to instructions from the Imperial Agriculture Department (Colonial Reports, 1911). This fund put in motion a process of land purchase and house building that soon proved to be timely, in guiding the response of the Colonial Government through the aftermath of two significant natural hazard events: a hurricane in 1898 that affected the whole island, and the volcanic eruption of 1902-3 that devastated many communities in the north of St Vincent. At first, however, the process moved only slowly; with estate owners in no hurry to sell up, or to relinquish their hold on tenant labourers; and the local people in little hurry to purchase and settle on lands that may be distant from the estates, and that required a commitment to the production of economic crops (Colonial Reports, 1903a, 1903b; John, 2006; Adams, 2002). 


\subsection{The great hurricane of 1898}

A major hurricane struck St Vincent in September 1898. This dealt a further blow to the already-weakening sugar economy, and accelerated the re-distribution of land from abandoned estates towards the exploitation of crops less dependent on infrastructure such as processing mills (Richardson, 1997). The hurricane caused significant damage across the whole island, and 'not a single estate works .. escaped injury' (Blue Book, 1899b, §26). The hurricane left 20,000 people homeless and killed 225, with total losses estimated at $£ 225,000$ across St. Vincent (Blue Book, 1899a; Table 2). Commentators noted that the hurricane was 'in every way far more destructive' than that of 1831 (Blue Book, 1899b, §28).

The Botanical Station on St. Vincent provided an important stimulus to the recovery process. The station had been established in 1765 , and for some decades had been in the forefront of experimentation in crop growing in the Caribbean (Howard, 1954). After falling into disrepair, it was re-established in 1890 under the curatorship of Henry Powell. In 1898, following the Royal Commission report, funding was provided by the Colonial Office for the Botanical Station to expand its activities, including setting up an experimental station and agricultural school to improve and adapt agricultural practices and to pass them on; and to grow plants for sale and distribution.

After the hurricane, agricultural officers were quick to assess the damage, and saw the opportunity to encourage small holders to plant new seeds to hasten recovery. On 30th September 1898 Governor Moloney reported 'The present is the time for planting out, and I have had distributed .. sweet potato cuttings, Indian corn seeds, and quick growing peas and beans.' (Blue Book, 1899b, §43; Powell, 1900). It was recognized that the planting of lines of trees as windbreaks had helped to protect cocoa trees; and that landslides and floods had been the chief causes of crop losses in some estates. By late October 1898 the Botanical Station had provided seeds and plants to over 500 people, sufficient to plant 377 acres (Blue Book, 1899a, §87).

The rapid response to the emergency from London included authorized expenditure of the $£ 15,000$ Imperial Grant; an additional $£ 25,000$ to cover expenses of relief, rehousing and repairs of public works, and a loan of $£ 50,000$ for Estate owners, to meet their 'immediate difficulties' (Blue Book, 1899a, §80). Considerable funds were also provided from the Lord Mayor of London's Mansion House fund and private donations, to assist the many islands affected by the storm.

In the aftermath of the hurricane, relief centres were established within days. 'All churches and public buildings left standing were used for (shelter) in September and October', and temporary shelters were erected in all the main population centres. For the month after the hurricane, 10,000 people were sheltered in Government buildings, and $30,000-35,000$ were in receipt of relief. The Colonial Office in London pressed the Governor to accelerate the purchase of lands for settlement to re-house the many homeless (Blue Book, 1899a, §52). By the end of 1899, 4400 acres of land had been bought; the majority in the Cumberland and Linley Valleys (Leeward), with smaller plots at Richmond Hill

Table 2

Assessed losses (in GBP) due to the 1898 hurricane and 1902 eruptions.

\begin{tabular}{|c|c|c|c|}
\hline 1898 hurricane $^{a}$ & & 1902 eruptions $^{\mathrm{b}}$ & \\
\hline Losses in the Townships & 28,735 & Land & 19,350 \\
\hline Damage to properties & 139,521 & House property & 10,000 \\
\hline Losses to Church Property & 27,440 & Stock & 7500 \\
\hline Destruction of public buildings & 14,348 & Furniture and Clothing & 2000 \\
\hline \multirow{3}{*}{$\begin{array}{l}\text { Damage to crops and dwellings in the } \\
\text { out-districts }\end{array}$} & 15,000 & Produce & 20,000 \\
\hline & & Miscellaneous & 6500 \\
\hline & & $\begin{array}{l}\text { Indirect (loss of } \\
\text { earnings etc.) }\end{array}$ & 13,500 \\
\hline Total & 225,045 & Total & 78,850 \\
\hline
\end{tabular}

a Assesssed in February 1899, Governor Moloney (Blue Book, 1899a, §119).

b Assessed in December 1902. Capt Young (Blue Book, 1903, §91).
(Kingstown), and New Adelphi and Park Hill (Windward; Colonial Reports, 1901).

Although it was highly destructive, the hurricane provided a further and immediate stimulus for land reform, and helped to advance the establishment of the new small-holdings and settlements, and the planting out of food and economic crops. This proved to be an important backdrop to the re-awakening of the volcano three years later, by reducing the barriers to emergency re-housing of the displaced; and by offering another opportunity to diversify plant growing and crop production.

\section{The 1902-1903 eruptions of St Vincent, and their impacts}

During 1901, the first signs of unrest at the Soufrière volcano were noticed: small earthquakes were felt, first by the people who lived on and around the flanks of the volcano, and during April 1902 there were reports of increasing numbers of earthquakes, rockfalls and landslides. In the analysis below, we focus on the events that were reported by a variety of observers that describe the eruptions that began in May 1902, and explore the emergency response to the volcanic crisis, and the relief efforts that followed.

\subsection{Documentary records}

In the late 19th Century there was a strong tradition of amateur observers documenting and writing about the environment, whether in books, journals or periodicals (Dawson et al., 2015). Many of the 'professional' classes employed by the Colonial Governments in Barbados and St. Vincent worked in an environment where systematic note-taking was essential to the execution of their own work. As a result, the physical, social and economic impacts of the eruption of the Soufrière St. Vincent are minutely documented in Colonial Office records (e.g. Blue Book, 1902, 1903). These reports also give a very clear view of the management of relief efforts by the Colonial Government, and of the discussions about emergency response, emergency relief, compensation for losses and planning for the future. Some of the Colonial Office telegrams and reports of the eruption were also published in contemporary newspapers, and we have drawn on some of these records to augment the timeline of events (Supplementary Table 1).

The destructive eruptions on both St. Vincent and Martinique also attracted a steady stream of scientific observers, who later published their observations in books, magazines and scientific papers (Table 3). While many of these sources contain eyewitness accounts, it is a legacy of the times that there are few contemporary accounts from the people who were most badly affected by the eruptions. Where possible we have supplemented the contemporary observations with the cultural memories of eruptions re-told by second or third generation descendants of survivors during semi-structured interviews in 2014 (Armijos and Few, 2016).

The most complete analysis of the 1902 eruptions of the Soufrière of St Vincent was published by Anderson and Flett in 1903, based on their fieldwork in the immediate aftermath of the eruption (Table 3). This monumental work in fact only assesses the progress of the eruption during May and June 1902, and is principally an analysis of the May 7th eruption. Later episodes of activity have been somewhat neglected, but were documented in Colonial records (Blue Book, 1902, 1903), and in Anderson (1908), whose chronology of events included reports of mud flows and other secondary phenomena.

\subsection{Eruption chronology: May 1902-March 1903}

In May 1902, the volcano of St Vincent entered into a violent eruption that sent ash high into the atmosphere, and cascades of pyroclastic density currents and lahars down the volcano flanks, and into the drainages that dissect the northern parts of St Vincent. After reaching a culmination on May 7th, 1902, the volcano had later outbursts in May, September and October 1902, and a final explosion in March 1903. 
Table 3

Scientific observations, records and reports.

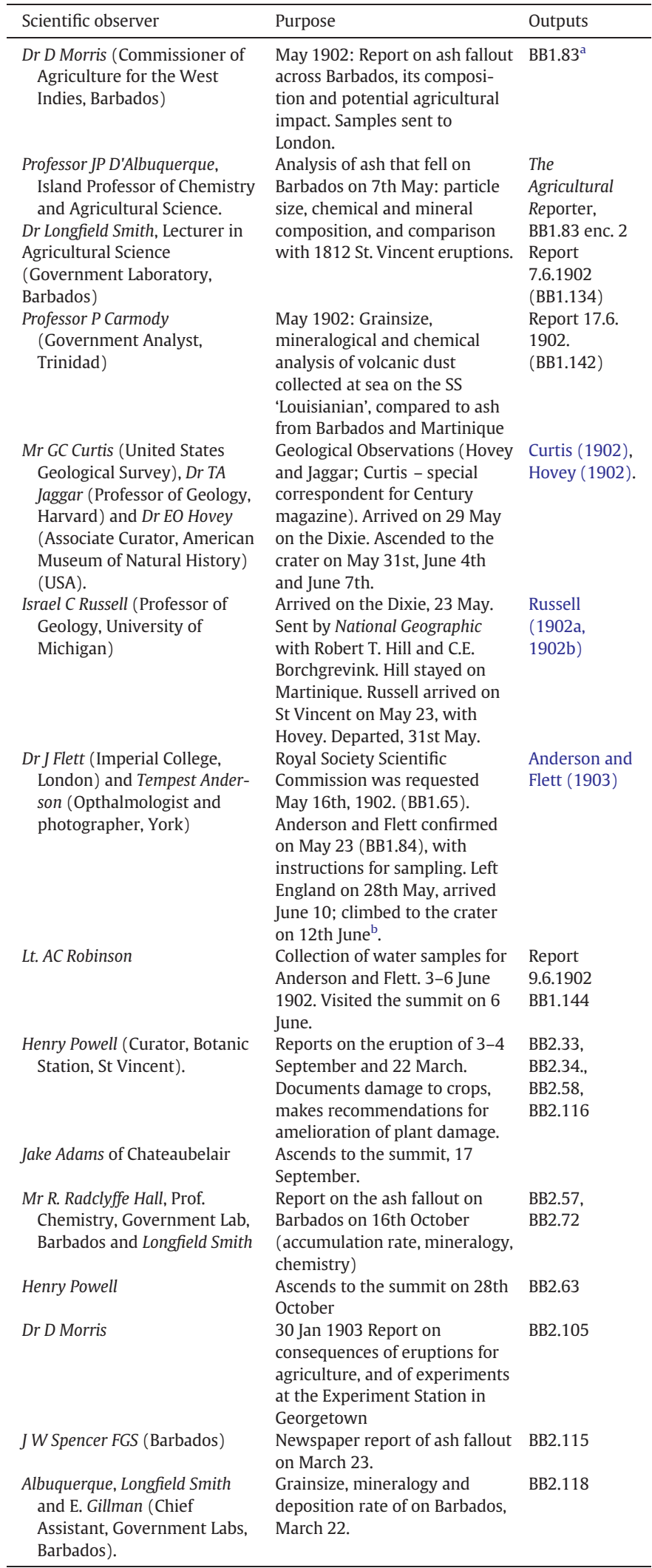

a 'BBx.xx' refers to the appropriate section from the Parliamentary Correspondence relating to the eruptions (Blue Book, 1902, 1903).

b Dates of arrival, summiting, and so on are confused; with different versions in the Blue Book (1902), Anderson and Flett (1903) and other sources.
Table 4

Summary description of volcanic activity and immediate impacts and emergency actions by population.

\begin{tabular}{|c|c|c|}
\hline Date/activity & $\begin{array}{l}\text { Population } \\
\text { movement/response }\end{array}$ & Description/source \\
\hline $\begin{array}{l}\text { Pre-cursory } \\
\quad \text { earthquakes } \\
\text { (Feb-April } 1902\end{array}$ & $\begin{array}{l}\text { Initial evacuations from } \\
\text { Morne Ronde }\end{array}$ & $\begin{array}{l}\text { Anderson and Flett (1903), } \\
\text { Cox (2004) }\end{array}$ \\
\hline $\begin{array}{l}\text { May 5-6th - changing } \\
\text { lake levels at } \\
\text { Soufrière, some } \\
\text { phreatic activity. }\end{array}$ & & $\begin{array}{l}\text { Newspaper reports } \\
\text { (Supplementary Table 1), } \\
\text { Fisherwoman's } \\
\text { observations, narratives } \\
\text { from interviewees in 2014. } \\
\text { Anderson and Flett (1903) }\end{array}$ \\
\hline $\begin{array}{l}\text { May 6th - initial } \\
\text { explosions }\end{array}$ & $\begin{array}{l}\text { Rumbling heard and } \\
\text { earthquakes felt at Wallibu } \\
\text { during the morning. } \\
\text { At around } 3 \text { pm, a cloud of } \\
\text { steam burst from the crater. } \\
\text { People from the north } \\
\text { Leeward side began to } \\
\text { arrive in Chateaubelair. } \\
\text { Morne Ronde was deserted } \\
\text { by } 5 \text { pm. Wallibu and } \\
\text { Richmond evacuated by } 6 \\
\text { pm. ' } 300 \text { fed last night'. } \\
180-200 \text { people stayed in } \\
\text { the Government Barracks } \\
\text { overnight, and } 150 \text { refugees } \\
\text { from Morne Ronde went to } \\
\text { Rose Bank. }\end{array}$ & $\begin{array}{l}\text { Anderson and Flett (1903); } \\
\text { BB1.2, from Governor } \\
\text { Llewellyn (RBL); BB1.82B, } \\
\text { from WJ Calder, Chief of } \\
\text { Police; BB1.113, report } \\
\text { from RBL. }\end{array}$ \\
\hline $\begin{array}{l}\text { May 7th a.m. Further } \\
\text { explosions }\end{array}$ & $\begin{array}{l}\text { Northern Leeward villages } \\
\text { nearly deserted. Wallibu } \\
\text { sugar mill was stopped at } 9 \\
\text { am, due to the steady } \\
\text { showers of dust. Windward } \\
\text { Estates sugar-making as } \\
\text { usual. }\end{array}$ & Anderson and Flett (1903) \\
\hline $\begin{array}{l}\text { May } 7 \text { th p.m. climatic } \\
\text { stages of main } \\
\text { eruption }\end{array}$ & $\begin{array}{l}\text { Windward side down to } \\
\text { Georgetown ( } 300 \text { at } \\
\text { Colonarie Police Station); } \\
\text { people in Chateaubelair } \\
\text { abandoning to boats. } \\
\text { Deaths largely incurred on } \\
\text { Windward side. } \\
\text { At Chateaubelair 'it was } \\
\text { evident that the eruption was } \\
\text { increasing in force and } \\
\text { extent, and a continuous } \\
\text { stream of people were } \\
\text { coming into the town from } \\
\text { the villages and hamlets in } \\
\text { the immediate vicinity of the } \\
\text { mountain'. } \\
1 \text { pm: Calder advised } \\
\text { people to leave } \\
\text { Chateaubelair; } 500-600 \text { left } \\
\text { on foot for Barrouallie. At } \\
6.30 \text { pm (Barrouallie), Rev. } \\
\text { Huckerby reports } 500 \\
\text { people in the school house } \\
\text { and mission dwelling. } \\
\text { 'Over } 300 \text { people are in } \\
\text { Georgetown at the school } \\
\text { house' 'Estate Lot } 14 \\
\text { destroyed' } \\
\text { 'Many deaths in the Carib } \\
\text { country [from Georgetown] } \\
\text { to Sandy Bay... The } \\
\text { destruction of Wallibu and } \\
\text { Richmond estates is } \\
\text { complete' }\end{array}$ & $\begin{array}{l}\text { Reports dated May } 7 \text { from } \\
\text { EJ Cameron (Administrator, } \\
\text { St Vincent (BB1.80); and } \\
\text { from Cameron, Police } \\
\text { Magistrate 'HBI' and } \\
\text { Sergeant-Major Beale, } \\
\text { dated May 8, (BB1.81), } \\
\text { Chief of Police Calder, dated } \\
\text { May 8, (BB1.82) }\end{array}$ \\
\hline May 9 & $\begin{array}{l}\text { 'Telephonic communications } \\
\text { to Georgetown restored. At } \\
\text { Barrouallie, there are some } \\
600-800 \text { refugees.'In.. } \\
\text { Georgetown cemetary } 82 \\
\text { were interred yesterday. Men }\end{array}$ & $\begin{array}{l}\text { Cameron and Police } \\
\text { Magistrate (HBI, GD; } \\
\text { BB1.82). }\end{array}$ \\
\hline
\end{tabular}


Table 4 (continued)

\begin{tabular}{|c|c|c|}
\hline Date/activity & $\begin{array}{l}\text { Population } \\
\text { movement/response }\end{array}$ & Description/source \\
\hline & $\begin{array}{l}\text { and carts were employed .. } \\
\text { for the purpose of burying all } \\
\text { dead bodies found on the } \\
\text { following estates.. Overland, } \\
\text { Tourama, Orange Hill, } \\
\text { Waterloo, Rabacca, and Lot } \\
\text { 14. Many of the bodies } \\
\text { interred yesterday have been } \\
\text { carted in from Waterloo, } \\
\text { Orange Hill, Rabacca and } \\
\text { Mount Bentinck estates; } \\
\text { many of these were found } \\
\text { dead on the roadside' }\end{array}$ & \\
\hline May 13 & $\begin{array}{l}\text { 'fear that } 1600 \text { killed; } 1000 \\
\text { bodies found and buried, } 160 \\
\text { sent into hospital in } \\
\text { Georgetown. } 2200 \text { received } \\
\text { relief. }\end{array}$ & BB1.36 \\
\hline May 14 & $\begin{array}{l}\text { 'Northern end of island } \\
\text { devastated from } \\
\text { Chateaubelair round to } \\
\text { Georgetown. Windward side } \\
\text { of island worse. About } 3000 \\
\text { under relief. }\end{array}$ & BB1.38 \\
\hline May 16 & $\begin{array}{l}\text { 'Total number of bodies now } \\
\text { found and buried, } 1300 \text {; in } \\
\text { hospital today, } 130.3000 \text { on } \\
\text { relief list today'. }\end{array}$ & BB1.59 \\
\hline $\begin{array}{l}\text { 21st May explosion } \\
(20: 30)\end{array}$ & $\begin{array}{l}\text { All businesses suspended; } \\
\text { 'fresh refugees' }\end{array}$ & $\begin{array}{l}\text { Anderson and Flett (1903); } \\
\text { Manchester Guardian } \\
\text { 22.5.02 }\end{array}$ \\
\hline 23rd May & $\begin{array}{l}\text { Number of deaths } \\
\text { estimated 1565; } 7000 \\
\text { people receiving immediate } \\
\text { rations at a cost of } 3 d \text { per } \\
\text { day. } 35 \text { families from Fraser's } \\
\text { placed on the Clare Valley }\end{array}$ & BB1.113 \\
\hline $\begin{array}{l}\text { 3rd September } \\
\text { explosion }\end{array}$ & $\begin{array}{l}1.20 \text { pm: Police warned } \\
\text { inhabitants of } \\
\text { Chateaubelair to leave, and } \\
\text { alerted Magistrate at } \\
\text { Georgetown. The 'majority } \\
\text { of people withdrew', } \\
\text { sheltering for the most part } \\
\text { with friends: on the } \\
\text { Windward side at } \\
\text { Colonarie, San Souci, Mount } \\
\text { Greenan; on the Leeward } \\
\text { side to Troumaca Hill, } \\
\text { Cumberland, Coull's Hill } \\
\text { and Barrouallie. } \\
\text { Chateaubelair and } \\
\text { Georgetown were } \\
\text { practically abandoned. } \\
\text { By } 8 \text { September 'some } 200 \\
\text { or more people were in } \\
\text { Chateaubelair, having come } \\
\text { in for the day from places } \\
\text { where they have taken } \\
\text { shelter. By } 9 \text { September, } \\
\text { people were returning to } \\
\text { Georgetown and to the } \\
\text { villages.' } \\
\text { Update on damage to crops, } \\
\text { concludes 'scarcely any } \\
\text { damage has been done... in } \\
\text { the consequence of their } \\
\text { being but little fit to reap. } \\
\text { From Rosebank and } \\
\text { Troumaca to Belmont Old } \\
\text { Sugar works, the damage } \\
\text { done to growing provisions is } \\
\text { severe.. and will probably } \\
\text { retard the growing season by } \\
6 \text {-8 weeks. The depth of the }\end{array}$ & BB2.34 \\
\hline
\end{tabular}

Table 4 (continued)

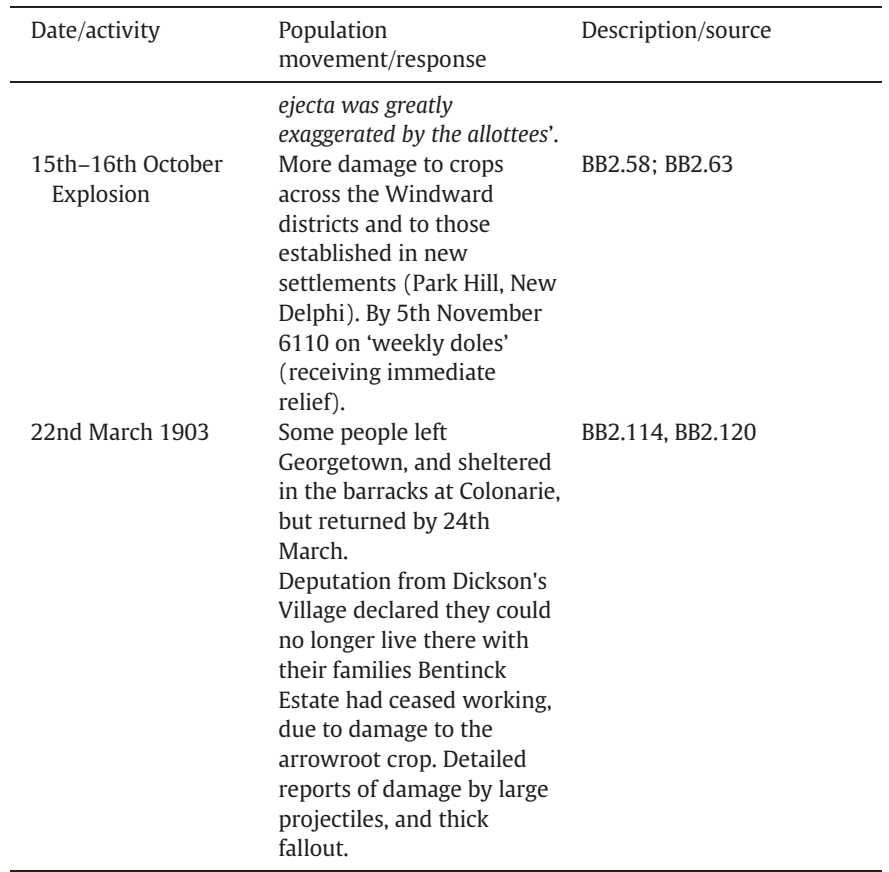

BBx.xx refers to the appropriate section of the Blue Book correspondence for 1902 (BB1) and 1903 (BB2).

From the contemporary accounts and records, augmented with some more recent analyses, we have reconstructed the timeline of events through 1902 and 1903. The principal activity of the volcano and the responses of the local population is summarised in Table 4. Table 5 documents the recorded responses and actions by those responsible for governance on the island as well as external agencies and individuals, and Tables 6 and 7 assess the populations affected in each area, details the rebuilding programme and list the sources of relief provided.

The physical volcanology of the eruption has not been closely studied since 1902; and is the subject of ongoing work. Here, we provide a very brief summary. The extent of direct tephra deposition during each eruptive episode can be inferred from official reports (Blue Book, 1902, 1903; Fig. 2), augmented by later field-based assessments of the areas affected directly by the May 7th 1902 hot avalanches (Hay, 1959; Roobol and Smith, 1975). There are no published isopach maps for any of the 1902-1903 deposits, although estimates of the total erupted volume $\left(1.4 \mathrm{~km}^{3}\right.$ of tephra, cited by Robson and Tomblin, 1966) may have been based on mapped evidence. Robertson (1995) presented a hazard map for the volcano, describing one of the boundaries as based on the ' $5 \mathrm{~cm}$ isopach' of the 1902 eruption. Isopach maps presented in Fig. 2 are based entirely on details recorded at the time, principally by the Curator of the Botanic Garden, Henry Powell (Blue Book, 1902, 1903). One 'distal' point is provided from the Agricultural Station on Barbados, supplemented by the brief reports of ashfall following the May 7th eruption that was recorded by ships across the region (e.g. Page, 1902).

\subsection{Emergency movements of population}

The rapid onset of the May 1902 eruptions caught many people unaware, and contributed to the high death toll. But other factors also came into play. The most marked distinction in response to the eruption was between those on the Windward (Eastern) and the Leeward side of the island (See Table 4 and Fig. 1). Both were impacted equally by the products of the eruption, but the majority of those on the Leeward side had responded to the precursory activity on May 6th, and moved out of 'harms way' by the morning of the 7th of May. This was attributed by Anderson and Flett (1903) to the clearer line of site to the initial 
Table 5

Timeline: emergency responses, governance decisions and relief from external sources.

\begin{tabular}{|c|c|c|}
\hline Date & Event & Reference $^{\mathrm{a}}$ \\
\hline 7 May 1902 & $\begin{array}{l}\text { Violent explosive eruption of the Soufrière, St } \\
\text { Vincent. Governor Llewellyn }\left(\mathrm{RBL}^{\mathrm{b}}\right) \text { departed St } \\
\text { Vincent for St Lucia }(10 \mathrm{am}) \text {. Submarine cables } \\
\text { from St Lucia to St Vincent and Grenada broke, } 3 \\
\text { pm. }\end{array}$ & BB1.3, BB1.79 \\
\hline
\end{tabular}

8 May 1902 Destructive explosive eruption of Mt Pelée, Martinique. St Pierre destroyed, with great loss of life.

8 May 1902 Coasting steamer 'Wear' dispatched from St Lucia to St Vincent.

9 May 1902 Commander in Chief of West Indies Admiralty, Bermuda, requests HMS Indefatigable to collect RBL from St Lucia.

10 May 1902 HMS Pallas to take supplies from Jamaica to St Vincent

10 May 1902 HMS Indefatigable departs Trinidad with a 'deck load of supplies' to St Vincent, then St Lucia and Martinique. 'Salt fish, corn meal, crackers, rice, flour, very acceptable. 3000 people in receipt of relief'.

10 May 1902 RBL fails to leave St Lucia on the coasting steamer BB1.14 as 'it narrowly escaped being wrecked yesterday', awaits HMS Indefatigable.

12 May 1902 Colonial Secretary $\left(J^{b}\right)$ authorises Governor of the BB1.25 Windward Islands (RBL) to spend $£ 10,000$ from the Crown Agents of the Colonies 'at once, and more if necessary'

12 May 1902 Army Medical Service team depart from Barbados on Royal Mail Steamer Solent, with field medical and surgical equipment.

RBL arrives back on St Vincent. Coasting steame Wear carrying water and provisions along Leeward coast.

14 May 1902 HMS Indefatigable departs Barbados, with two civil BB1.66 medical officers and 'large quantities of medical stores and general provisions'.

14 May 1902 JC asks Lord Mayor of London to open the Mansion BB1.45 House Fund 'for the relief of the numerous sufferers by this melancholy disaster'.

14 May 1902 US Auxiliary Cruiser 'Dixie' left New York, and US BB1.98, collier 'Sterling' left San Juan for Martinique and St BB2.10 Vincent. 'These two vessels carry sufficient provisions to allow of rations for 36 days for 50,000 people'. [Dixie arrived on 24 May].

16 May 1902 Colonial Office ask the Royal Society whether they BB1.65 might send scientific observers to the West Indies 'to study the scenes of the recent eruptions', but 'cannot hold out any hope of any special government grant for this purpose'.

17 May 1902 'All immediate wants are now supplied'. RBL has ordered $£ 5000$ worth of timber from US and Canada. 'One new township has been settled up to the present time'.

18 May 1902 Small eruption of Soufriere, St Vincent.

20 May 1902 Royal Mail Steamer 'Para' offered free carriage of stores or money from Jamaica to St Vincent and Martinique.

21 May 1902 Governor of Jamaica offers assistance by receiving settlers. 'United Fruit Company offer accommodation and work for 200 or 300'.

22 May 1902 Messrs. Pickford and Black offer free transport of reasonable quantities of supplies for relief, from Halifax, Canada.

23 May 1902 RBL report's on the loss of life and damage..' No assistance will be given to anyone who may wish to return to the devastated areas.

11 June 1902 JC agrees 'to the remission of land tax for one year on the estates enumerated [in BB1.113]'.

6 June 1902 RBL reports on the distribution of the fund for relief. Expects to feed 5000 people for six months. Wishes to use relief funds to restore the canal, roads and fordings. Proposes to rehome 500 families in new homes. Huts and land under this scheme to remain on trust for 10 years and planting conditions imposed. Compensation: to

BB1.70
Table 5 (continued)

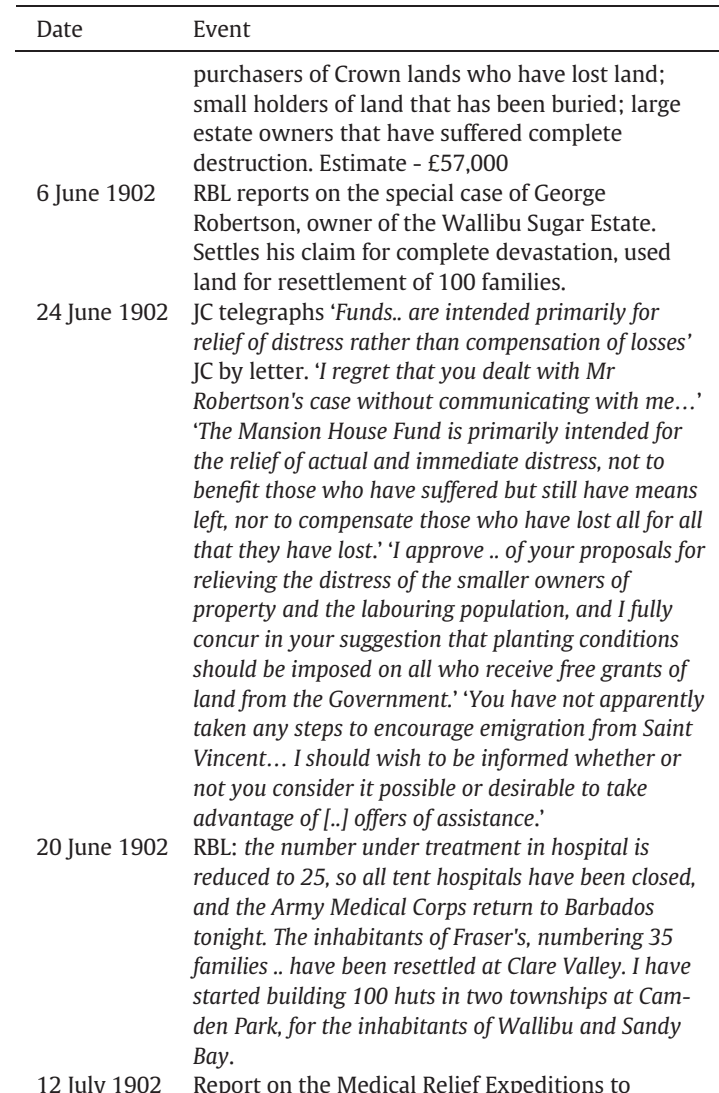

Report on the Medical Relief Expeditions to
Martinique and St Vincent.

16 July 1902 RBL: sets out plans for compensation. Proposes a fixed-valuation scheme to compensate for losses of (1) livestock; (2) furniture and clothing; (3) total loss of or damage to dwelling houses and estate buildings; (4) land completely buried; (5) land purchased from the Crown in small lots and now destroyed. In cases of (3), (4) owners will renounce all interest in the land.

18 July 1902 RBL: schedule of damage to church property and schools

18 July 1902 Ladies Clothing Committee in St. Vincent reports. They started work on 10th May, and distributed over 4700 suits of clothing, remaining clothing to be held and distributed on rehousing.
19 August 1902

BB1.126

BB1.75

BB1.78

BB1.113

BB1.113

BB2.1 1902

25 1902
BB2.2

BB2.4

JC: 'I think it essential that property should not be purchased with the [Mansion House] fund, except for the single purpose of affording relief to those sufferers for whose assistance it was contributed.'

3 September Alex Porter (Estate Owner) sets out his complaints BB2.22 1902 about his lack of compensation to the Colonial Office, in particular focusing on water supplies to the north via canal.

3-4 Eruption of Soufriere, St Vincent. September September

Following demonstrations, riots and petitions, RBL BB2.30, Plans to pay for passage, to resettle families in BB2,32; Jamaica, in housing similar to the new houses on St BB2.40; Vincent. Names are gathered, discussion between $\mathrm{RBL}$ and JC on continuation of rations for those who refuse.

14 October Colonial Office: Captain Arthur Young appointed as BB2.41 1902 special officer to supervise relief and resettlement efforts.

15-16 Large eruption of Soufriere, St Vincent. Ash fallout on October Barbados.

1902

20 October RBL: 'Popular agitation .. against any emigration.' 
Table 5 (continued)

\begin{tabular}{|c|c|c|}
\hline Date & Event & Reference $^{a}$ \\
\hline $\begin{array}{l}24 \text { October } \\
1902\end{array}$ & $\begin{array}{l}\text { JC: 'Use influence to induce them accept offer. If they } \\
\text { still decline.. await arrival of Young' }\end{array}$ & BB2.50 \\
\hline $\begin{array}{l}23 \text { October } \\
1902\end{array}$ & $\begin{array}{l}\text { RBL: 'The area of safety for dwellings and } \\
\text { cultivation are gradually getting reduced.. The } \\
\text { south-eastern end of the island is badly off for } \\
\text { water, and I am afraid if more people are crowded } \\
\text { there they will not be able to exist. Forced } \\
\text { emigration seems the only solution..' }\end{array}$ & BB2.58, 59 \\
\hline $\begin{array}{l}23 \text { October } \\
1902\end{array}$ & $\begin{array}{l}\text { Governor, Belize to Colonial Office: Mr Cramer of } \\
\text { Sarstoon offers to take } 100 \text { labourers. }\end{array}$ & BB2.61 \\
\hline $\begin{array}{l}15 \\
\text { November } \\
1902\end{array}$ & $\begin{array}{l}\text { JC to RBL: 'not inclined to sanction emigration to } \\
\text { what is described as a very remote district..' }\end{array}$ & BB2.62 \\
\hline $\begin{array}{l}5 \text { November } \\
1902\end{array}$ & $\begin{array}{l}\text { RBL report: ' } £ 2000 \text { per month is now required to } \\
\text { keep the people from starving; about half is issued as } \\
\text { 'doles', and the other is worked for on relief works on } \\
\text { public roads.. } 6110 \text { people are now receiving weekly } \\
\text { doles, } 1450 \text { are engaged on road making. } 300 \text { huts } \\
\text { have been built, and families located, and about } 300 \\
\text { more are required.. but there are many single persons } \\
\text { and women with .. families deserted by the fathers } \\
\text { who will have eventually to be found lodgings.' }\end{array}$ & BB2.63 \\
\hline $\begin{array}{l}5 \text { November } \\
1902\end{array}$ & $\begin{array}{l}\text { WM Everard Stephens petitions the Colonial Office, } \\
\text { on behalf of the people of Fancy and Owia, asking } \\
\text { for land to be purchased for resettlement. }\end{array}$ & BB2.64 \\
\hline $\begin{array}{l}20 \\
\text { November } \\
1902\end{array}$ & $\begin{array}{l}\text { RBL to JC. 'Emigration can be arranged only on } \\
\text { compulsion.. May I purchase some more land?' }\end{array}$ & BB2.65 \\
\hline $\begin{array}{l}20 \\
\quad \text { November } \\
1902\end{array}$ & $\begin{array}{l}\text { Rowntree and Co. Ltd. offer employment in } \\
\text { Dominica for 50-100 families. }\end{array}$ & BB2.66 \\
\hline $\begin{array}{l}25 \\
\text { November } \\
1902\end{array}$ & $\begin{array}{l}\text { Mansion House St Vincent Relief Fund closes, } \\
\text { balance paid to the Crown Agents for the Colonies. }\end{array}$ & BB2.69 \\
\hline $\begin{array}{l}25 \\
\text { November } \\
1902\end{array}$ & JC: 'The situation.. is causing me very great concern'. & BB2.67 \\
\hline $\begin{array}{l}26 \\
\text { November } \\
1902\end{array}$ & $\begin{array}{l}\text { JC: 'Consider that emigration should be pressed as far } \\
\text { as possible. If reluctance to emigrate is to some } \\
\text { degree due to possibility of obtaining relief from the } \\
\text { Government, .. refuse relief to able-bodied applicants } \\
\text { over sixteen, except in return for a bona fide day's } \\
\text { work' }\end{array}$ & BB2.70 \\
\hline $\begin{array}{l}26 \\
\text { November } \\
1902\end{array}$ & $\begin{array}{l}\text { Colonial Office to Rowntree 'There is every desire to } \\
\text { encourage emigration.. but great difficulty is being } \\
\text { experienced in inducing people to move..' }\end{array}$ & BB2.71 \\
\hline $\begin{array}{l}18 \\
\quad \text { November } \\
1902\end{array}$ & $\begin{array}{l}\text { RBL to JC. Forwards a petition, with cover letter. 'I } \\
\text { deny that anyone in the Colony is starving!'. 'No } \\
\text { attempt at compulsory emigration has been proposed } \\
\text { by me..' }\end{array}$ & BB2.74 \\
\hline $\begin{array}{l}18 \\
\text { November } \\
1902\end{array}$ & $\begin{array}{l}\text { Edward Cameron (Administrator to St. Vincent) to } \\
\text { RBL: note on food supplies shipped to St Vincent } \\
\text { including 'an enormous quantity of miscellaneous } \\
\text { provisions, of which the predominant item was rice.. } \\
\text { landed here by the USS Dixie'. These supplies were } \\
\text { given as rations from May - August, and then doles } \\
\text { in lieu were paid from late July/August. 'A large } \\
\text { quantity of goods.. has been sold [including] fish, } \\
\text { bacon, hams, tea, bread, coffee, vinegar, currants... } \\
\text { and notably rice [since] the supply poured on us was } \\
\text { immense' } \\
\text { 'It would have been better in some ways if money } \\
\text { relief has been given from the first, instead of food'. }\end{array}$ & BB2.74 enc. 2 \\
\hline \multirow[t]{2}{*}{$\begin{array}{l}13 \text { December } \\
1902\end{array}$} & $\begin{array}{l}\text { 3rd report from Captain Young to RBL, outlining } \\
\text { the concerns of the inhabitants of Owia and Fancy. } \\
\text { 'My opinion is that with Owia and Fancy villages in } \\
\text { the flourishing condition that they are.. the people of } \\
\text { these villages would prefer to run the risk of the } \\
\text { volcano than to emigrate' }\end{array}$ & BB2.86 \\
\hline & $\begin{array}{l}\text { RBL to Young. 'I think that separate houses should no } \\
\text { longer be erected, but refuges provided.. for women } \\
\text { and children only. All males over } 16 . . \text { must look out } \\
\text { for themselves, and find work in neighbouring } \\
\text { islands. Relief work in St Vincent on roads should, as } \\
\text { a rule, be stopped, or at any rate no one should be }\end{array}$ & BB2.86 enc. 2 \\
\hline
\end{tabular}

Table 5 (continued)

\begin{tabular}{lll}
\hline Date & Event & Reference $^{\text {a }}$ \\
\hline & $\begin{array}{l}\text { employed who can obtain work in any other } \\
\text { neighbouring island.' }\end{array}$ & \\
24 December & $\begin{array}{l}\text { RBL to JC 'Young reports by telegram that even after } \\
\text { 1902 }\end{array}$ & BB2.83 \\
& emigrate under any conditions'
\end{tabular}

29 December Report by Captain Young to the Colonial Office.

1902 Detailed report, summarising his proposals: including (32) assessment of the area of taxed land damaged in the eruption (12,500 acres, of 40,281); (71) The policy of purchasing land from estate holders and settling thereon peasant proprieters should.. be extended .. on a cooperative system; (87) recommends that efforts be made to find US and Canadian markets for arrowroot; (89) proposes a bonus system to encourage planting of coconuts, cocoa, nutmeg and other spices; (107) proposes abolition of export duty, introduction of a house tax, and revisions to the land tax;

7 January Governor of Trinidad to JC: report indicating that BB2.96

1903 only 13 of 263 Vincentians who arrived in Trinidad to take up work after the hurricane of 1898 remained in post in 1902.

7 February Secretary of State to RBL 'You should fix date after $1903 \quad$ which all relief and relief work will be stopped.. You should remit balance of funds to Crown Agents for

BB2.91 enc. 3 investment.. People of Owia and Fancy must be held to have claim for special treatment'

27 January $\quad$ RBL to JC 'I am afraid that the views of Captain Young BB2.104 1903 as to purchasing sugar estates and allowing persons of the labouring class to work them on the co-operative system would not prove a success'

22 March Large eruption of Soufriere, St Vincent. Ash fallout on 1903 Barbados.

26 March Morris, Commissioner for Agriculture 'I believe that BB2.116

1903 the greater part of the island .. a little south of a line drawn across from Georgetown to Chateaubelair is still comparatively safe... The people of St Vincent .. should start as soon as possible the cultivation of fruit, cotton and other produce.. to maintain themselves and their families on lands that are practically beyond the reach of any volcanic action'

10 April 1903 RBL to Administrator, SV (Cameron). 'I direct you to BB2.120 erect as fast as possible as many temporary moveable huts as you can on rented land outside the danger zone' 'The people who occupy them should understand they are only given as temporary shelters. I will not buy more land.'

21 April 1903 Cameron to RBL: summarises details of 453 houses, BB2.124 now completed. 156 families still to be housed, of whom 49 are still in the Commissariat Building, and the remainder scattered among friends. There still remains to be tabulated and dealt with such refugees as are in the Barracks at Layou, Barrouallie and Chateubelair. Most of these will be accommodated at Mt Wynne.

20 May 1903 Total receipts have been about $£ 77,000$, expenditure up to date approximately $£ 37,000$

14 August Erection of 264 houses, including 100 for the 1903 villagers of Dixons. The Commissariat building at Edinburgh is at length empty. Layou and Barrouallie barracks will shortly be taken down. There are about 30 more cases to be considered. The Colonarie shelter barracks must remain for a time, in case there should be any further activity of the mountain.

\footnotetext{
a RBL, Governor of Windward Antilles Robert Llewelyn, JC, Joseph Chamberlain MP, UK Secretary of State for the Colonies.

b BBx.xx refers to the appropriate section of the Blue Book correspondence for 1902 (BB1) and 1903 (BB2).
}

explosive activity of the volcano on the Leeward side and the assumption on the Windward side that the 'dark clouds' were meteorological rather than volcanological. Governor Llewellyn's report of the eruption noted that 'At Georgetown and the 'Carib Country' on the windward side no signs of anything unusual occurred and the people there did not realise 
Table 6

Populations impacted by the 1902-3 eruptions of Soufrière, St. Vincent.

\begin{tabular}{llll}
\hline \multicolumn{4}{l}{ A. Estimated populations ${ }^{\mathrm{a}}$ in devastated areas. } \\
\hline Leeward & \multicolumn{3}{l}{ Windward } \\
\hline Richmond & 400 & Fancy & 190 \\
Wallibu & 250 & Gramacoo & 30 \\
Frasers & 230 & Owia & 350 \\
Morne Ronde & 200 & Sandy Bay & 230 \\
Windsor Forest & 12 & God Save the King & 30 \\
Baleine & 10 & Overland & 500 \\
Campobello & 30 & Turema & 400 \\
& & Orange Hill & 400 \\
& & Lot 14 & 320 \\
& & Waterloo & 300 \\
Total & & Rabacca & 300 \\
& 1132 & Langley Park & 200 \\
& & & 3250
\end{tabular}

B. Locations and numbers of houses ${ }^{\mathrm{b}}$ built for displaced communities.

\begin{tabular}{|c|c|c|c|}
\hline & \multicolumn{2}{|c|}{ April $1903^{c}$} & \multirow[t]{2}{*}{ August 1903} \\
\hline & $1 \mathrm{st}$ lot & 2nd lot & \\
\hline Camden Park (Sandy Bay) $^{\mathrm{d}}$ & 52 & & \\
\hline Camden Park (Wallibou) & 46 & & \\
\hline Clare Valley (Frasers) & 38 & 17 & \\
\hline Rutland Vale (Richmond) & 97 & & \\
\hline Rose Bank (Morne Ronde) & 26 & & \\
\hline Troumaca Hill (sundry) & 5 & & \\
\hline Richmond Hill (sundry) & 16 & & \\
\hline Park Hill (sundry) & 43 & 1 & \\
\hline Arnos Vale & & 60 & \\
\hline Questelles & & 18 & \\
\hline New Adelphi & & 15 & \\
\hline Mount Wynne & & 19 & 22 \\
\hline Colonarie Vale & & & 100 \\
\hline Mount Greenan & & & 30 \\
\hline Lower Diamond & & & 42 \\
\hline Grand Sable & & & 16 \\
\hline Three Rivers & & & 7 \\
\hline Wallilibo and Keartons & & & 17 \\
\hline Special cases in different localities & & & 30 \\
\hline Total & 323 & 130 & $264^{\mathrm{e}}$ \\
\hline
\end{tabular}

a Derived from the map of St Vincent, originally surveyed in 1861, annotated in 1902 to show the extent of devastation following the eruption of May 7,1902, with an estimate of the populations of the affected communities (Blue Book, 1902, §113). For population locations see Fig. 1.

b Houses were built to a stand specification $-16 \times 9$ square feet, on a plot of $100 \times 50$ square feet and an allotment of 3 acres of land per family. House cost was ca. £15 per house. Houses built on Morne Ronde were built to a prior specification, $14 \times 8$ square feet, at a cost of $£ 7$ (Blue Book, 1903, §40, §75, §124). 3 schoolhouses were also built, at Troumaca, Layou and Campden Park (Blue Book, 1903, §130).

c Many Lot 1 houses were built between May and July 1902; Lot 2 houses were completed between 21st March and 7th April 1903 (Blue Book, 1903, §6, §124).

d Origins of displaced occupants are given in brackets, where known (Blue Book, 1903, $\S 124, \S 131)$.

e All houses were reported occupied by 14 August 1903 (Blue Book, 1903, §131).

any danger until about midday on the 7th when the volcano was in full eruption. The sugar works were busy finishing up the crop and the people were all at work when suddenly the atmosphere became dark; sand and stones began to fall and the air was full of electricity. It is believed that at least 1,600 persons lost their lives between 2 pm and 3 pm' (Blue Book, $1902, \S 113)$.

On the Leeward side, there were few Estates north of Chateaubelair (Fig. 1 and Table 6) and it is.

likely that the population of Morne Ronde had already become anxious as a consequence of precursory earthquakes (Cox, 2004). Morne Ronde had been adversely affected by flooding and landsliding following the 1898 hurricanes, and the local population were already unsettled and negotiating for new lands. Sea-based evacuations were also easier on the Leeward side of the island, since there were established passenger canoe services between Chateaubelair and Kingstown, as well as trading and fishing boats (Musgrave, 1891).
Table 7

Sources and timeline of donations used to provide relief and assistance.

\begin{tabular}{|c|c|c|}
\hline Item & $\begin{array}{l}\text { Amount } \\
(£)\end{array}$ & Date offered/reference \\
\hline $\begin{array}{l}\text { Lord Mayor of London's Mansion } \\
\text { House Fund }\end{array}$ & 51,300 & $\begin{array}{l}15 \text { May } 1902 \text { Mansion House } \\
\text { Fund opened. BB1.45, BB1.48 }\end{array}$ \\
\hline Lord Mayor of Liverpool's Fund & 3240 & 16 September 1902 BB2.39 \\
\hline Legislative Council, Jamaica & 750 & $\begin{array}{l}15 \text { May } 1902 \text { BB1.54, } 75,127 \text { - } \\
\text { for settlement of labourers in } \\
\text { Jamaica }\end{array}$ \\
\hline Government of the Seychelles & 200 & 16 May 1902 BB1.61 \\
\hline Government of Dominica & 50 & 21 May 1902 BB1.110 \\
\hline $\begin{array}{l}\text { Government of the Turks and } \\
\text { Caicos Islands }\end{array}$ & 100 & 21 May 1902 BB1.74 \\
\hline Government of Canada & 5146 & 15 May 1902 BB1.46, BB1.114 \\
\hline Government of British Honduras & 102 & 23 May 1902 BB1.89, BB1.115 \\
\hline Government of Fiji & 100 & 31 May 1902 BB1.97 \\
\hline Government of Mauritius & 328 & 20 May 1902 BB1.71 \\
\hline Government of British Guiana & 1041 & 21 May 1902 BB1.108 \\
\hline Government of Barbados & 434 & 16 September 1902 BB2.39 \\
\hline Legislative Council, Grenada & 250 & 15 May 1902 BB1.105 \\
\hline Queen of the Netherlands & $\begin{array}{l}1000 \\
\text { florins }\end{array}$ & 21 May 1902 BB1.93 \\
\hline Queen-Mother of the Netherlands & $\begin{array}{l}250 \\
\text { florins }\end{array}$ & 29 May 1902 BB1.100 \\
\hline City of Berlin & 500 & 22 May 1902 BB1.94 \\
\hline $\begin{array}{l}\text { Belgian Minster of War: Military } \\
\text { Tournament and Carousel }\end{array}$ & 1348 & 13 August 1902 BB2.19 \\
\hline The Municipal Council, Mauritius & 32 & 20 May 1902 BB1.71 \\
\hline $\begin{array}{l}\text { Collected by the Editor, 'Mirror', } \\
\text { Trinidad }\end{array}$ & 174 & 20 May 1902 BB1.106 \\
\hline Collected by the Editor, 'Venezuelan & 78 & 16 September 1902 BB2.39 \\
\hline
\end{tabular}

Collected by the Editor, 'Dominica 26 Guardian'

Collected by the Editor, 'Royal 92

Gazette', Bermuda

'Irish Times' appeal from the

Commissioner of Montserrat

Collected in Berbice

Collected in Antigua

Collected in St Kitts

Collected in Montserrat

Collected in Sa

Collected in Fairview Presbyterian 4

Church, Vancouver, BC

Collected in the City of Mexico 29

Collected in Paramaribo

Collected in Inagua, Bahamas

Collected at Diamond Diggings,

British Guiana

Collected in St Andrew's, Grenada 18

Collected in Saba, by Mr E S Delisle, St 8 Kitts

Collected in St Croix

Collected in Dominica

Antwerp Relief Committe

16 September 1902 BB2.39

16 September 1902 BB2.39

16 September 1902 BB2.39

16 September 1902 BB2.39

30 Nov 1902 BB2.91 enc. 6

16 September 1902 BB2.39

16 September 1902 BB2.39

16 September 1902 BB2.39

16 September 1902 BB2.39

16 September 1902 BB2.39

30 Nov 1902 BB2.91 enc. 6

16 September 1902 BB2.39

16 September 1902 BB2.39

16 September 1902 BB2.39 16 September 1902 BB2.39

16 September 1902 BB2.39 16 September 1902 BB2.39 16 September 1902 BB2.49 21 October 1902 BB2.56

of the West Indian Sufferers (New York)

Funds raised in Sydney, Australia 97

Mr J Roland Duerden, Bermuda 5

Mr JB Kernahan, St Vincent

The Rev. Sheppard, Nevis

Messrs. JH Archer and Co., Trinidad 10

Mr EDM Hooper, Madras Forestry 5 Dept

NCOs and men of St Lucia Garrison 17

NCOs and men of Royal Army Medical 7

Corps in Barbados and Antigua

Net remittance from Barbados

Commercial Community of Barbados 185

Mr Win Wilson, Toronto

West Indians in Cape Town

ta Gertrudis Mining Company of 24 Pachuca

Fete at Malta

31 December 1902. BB2.85 16 September 1902 BB2.39 16 September 1902 BB2.39 16 September 1902 BB2.39 16 September 1902 BB2.39 16 September 1902 BB2.39

16 September 1902 BB2.39 16 September 1902 BB2.39

30 Nov 1902 BB2.91 enc. 6 16 September 1902 BB2.39 30 Nov 1902 BB2.91 enc. 6 30 Nov 1902 BB2.91 enc. 6 30 Nov 1902 BB2.91 enc. 6

30 Nov 1902 BB2.91 enc. 6 
Table 7 (continued)

\begin{tabular}{|c|c|c|}
\hline Item & $\begin{array}{l}\text { Amount } \\
(£)\end{array}$ & Date offered/reference \\
\hline $\begin{array}{l}\text { Direct remittance from the Finance } \\
\text { Committee, British Guiana }\end{array}$ & 33 & 30 Nov 1902 BB2.91 enc. 6 \\
\hline \multicolumn{3}{|l|}{ Sale of supplies } \\
\hline Barbados & 546 & 30 Nov 1902 BB2.91 enc. 6 \\
\hline Trinidad & 1252 & 30 Nov 1902 BB2.91 enc. 6 \\
\hline St Lucia & 25 & 30 Nov 1902 BB2.91 enc. 6 \\
\hline Grenada & 19 & 30 Nov 1902 BB2.91 enc. 6 \\
\hline Local (St Vincent) & 529 & 30 Nov 1902 BB2.91 enc. 6 \\
\hline Resale of land: Rutland Vale & 1600 & 30 Nov 1902 BB2.91 enc. 6 \\
\hline Sale of empty packages, etc. & 36 & 30 Nov 1902 BB2.91 enc. 6 \\
\hline $\begin{array}{l}\text { Refund of import duty on lumber } \\
\text { from Grenada }\end{array}$ & 50 & 30 Nov 1902 BB2.91 enc. 6 \\
\hline Total & $\begin{array}{l}\text { Ca. } \\
£ 72,750\end{array}$ & \\
\hline
\end{tabular}

Notes: BB1 and BB2 refer to the sections of the Parliamentary Correspondence: Blue Book (1902, 1903).

On the Windward side, things were a little different. Here, the summit of the volcano was not directly visible, and news of the state of the volcano would come from people who took the rough track from Georgetown to the Leeward side. Anderson and Flett (1903) reported the stories of some fish-sellers; and similar accounts are common elements of local memories.

'At that time she [ her mother] told me that in 1902 when the Soufrière exploded her mother was living in Point Village in a thatched house. Her mother and her grandfather and other siblings were living there. When the ash started falling like rain, she said in 1902, people used to walk from Georgetown to Leeward, and they would sell fish. A man had a donkey and when he was going over to Leeward he saw what was happening with Soufrière, so he came back and told the people that the Soufrière was going to erupt. Some people took heed and some didn't.'

[[Female interview, Fancy, 2014]]

'She [her guardian] told me that she had visited the La Soufrière before 1902 and she never went back. As a youth I told her about the deep lake that was there with blue water, she told me that before she visited it in 1902 it was not like that. She would say as soon as you reach the hill there was a big pool of blue water before you. She says this is how they suspected an eruption. In fact, her relatives were the ones who were crossing the hill. They came from the Leeward end and sold fish. There was a funeral over by Georgetown, her relatives came over, brought fish, came to the funeral and were going back for fish to come back. They used to have Nine Night praise and Third Night Praise for the dead. So they were going to that and as soon as they reached the top of the hill they saw the lake steaming. So they divided into two groups, some went back to warn the folks at Lot 14 and Langley Park, and some went to the Leeward end to warn those there to move, because the whole thing is in fire. But it was heavy steam coming from it. It was steaming heavily so they warned people. She said some of the folks who died at Lot 14, if they had taken heed, many of them would not have died'.

[[Female interviewee Sandy Bay, 2014]]

On the morning of May 7th, normal activities including milling and heating of sugar had already commenced on the Windward estates. On the Leeward side, evacuations were already occurring in response to initial activity. During the 1898 Hurricane a protocol was established for sharing and providing information relevant to taking self-protective measures (Powell, 1898) and similar lines of communication and information sharing were used during the initial stages of the eruption (Blue Book, 1902; Anderson and Flett, 1903). However, no official orders to move were given. By the time of the unrest on the morning of May 7th, the Governor of the Windward Isles, Sir Robert Llewellyn who was usually resident in Kingstown had elected to leave the island for a pre-arranged visit in St. Lucia. Thus, all the movements of the population through the 6th-7th of May should be regarded as self-evacuation (Table 4).

Together these circumstances meant that during the climactic phase of the eruption in the afternoon of May 7th, the majority of the ca. 1600 casualties were those people living and working on and around the estates in north-eastern St Vincent (see 4.4; Blue Book, 1903, §97). In contrast to those killed by the hurricane, whose names are recorded in the National archives in Kew, we have not been able to find specific data on those who died. The demographics of those hospitalized with burns injuries (56 men, 98 women and 40 children; Blue Book, 1903, §10) attest to the fact the deadly currents moved through a variety of places associated with a range of daytime activities on the Estates and environs. For example, 'They have said that from Lot 14 there is a guy who, when the message came, he stayed back because he was cooking, and he stayed back to bring the food. He sent his wife and the rest of his children in front of him' [Female interviewee, Langley Park, 2014].

The contrast in the number of the casualties between the eruption of 1812 and 1902 may reflect the different scale of the eruptions (with 1902 being larger); the larger population and the (somewhat) better auditing of human lives lost in 1902; and it may also reflect the more distributed population across the estates, with people working on smaller fields perhaps closer to the path of pyroclastic density currents. The time of the day of the eruptive climax (in the middle of the working day, as opposed to the 1812 eruption, which is inferred to have reached its peak overnight) may also have meant that workers were caught out in the open, in hazardous locations.

'... she was living to the bottom of the village. She and my grandmother were very good friends. She had burns all over her back, neck, hands and feet. She said she was 10 years old when the volcano erupted in 1902. She was hiding under a copper, some iron things. You have a lot of them around the country, people used to use them for making cassava farine.

[[Female interviewee, Sandy Bay, 2014]]

Self-evacuation continued to be a response to renewed eruptive activity throughout 1902-3 (Table 4), and the lack of employment in the devastated areas meant that with each eruption the number of people receiving rations from a central location temporarily increased; particularly as the repeated episodes of activity over the eleven months (Tables 1 and 5) were long enough to have begun the process of regrowing crops, that was then thwarted by further ashfall (Table 4).

\subsection{Medical effects}

Within hours of the first major eruption on May 7th it became clear that there were large numbers of casualties (Table 4). On May 23rd, the Governor reported that 1295 had perished outright (a number that Anderson and Flett, 1903, suggested was 'certainly an underestimate'), that 70 more had died in hospital from their injuries, and 200 were missing, giving a total of 1565 presumed killed by the eruption (Table 4). Numbers of casualties published in the annual Colonial Reports indicate that 1327 deaths were registered as having been due to the eruption of the Soufrière during the financial year 1902-1903 (Colonial Reports, 1903a). This figure did not include numbers of refugees who later died of dysentery, or anthrax (Colonial Reports, 1903a; Blue Book, 1903, §63). The accounts of the expenditure of the Soufrière eruption fund at the time shows that casualties were still being buried in some numbers through early and middle 1903 (Supplementary Table 2), but it is not clear whether these were the recently perished; late accounts from outlying districts, or the burial of remains discovered long after the fatal event.

In the immediate aftermath of the eruption, the majority of the injured and dead were from the Windward coast north of Georgetown. From the available information, residents of the Leeward coast north 

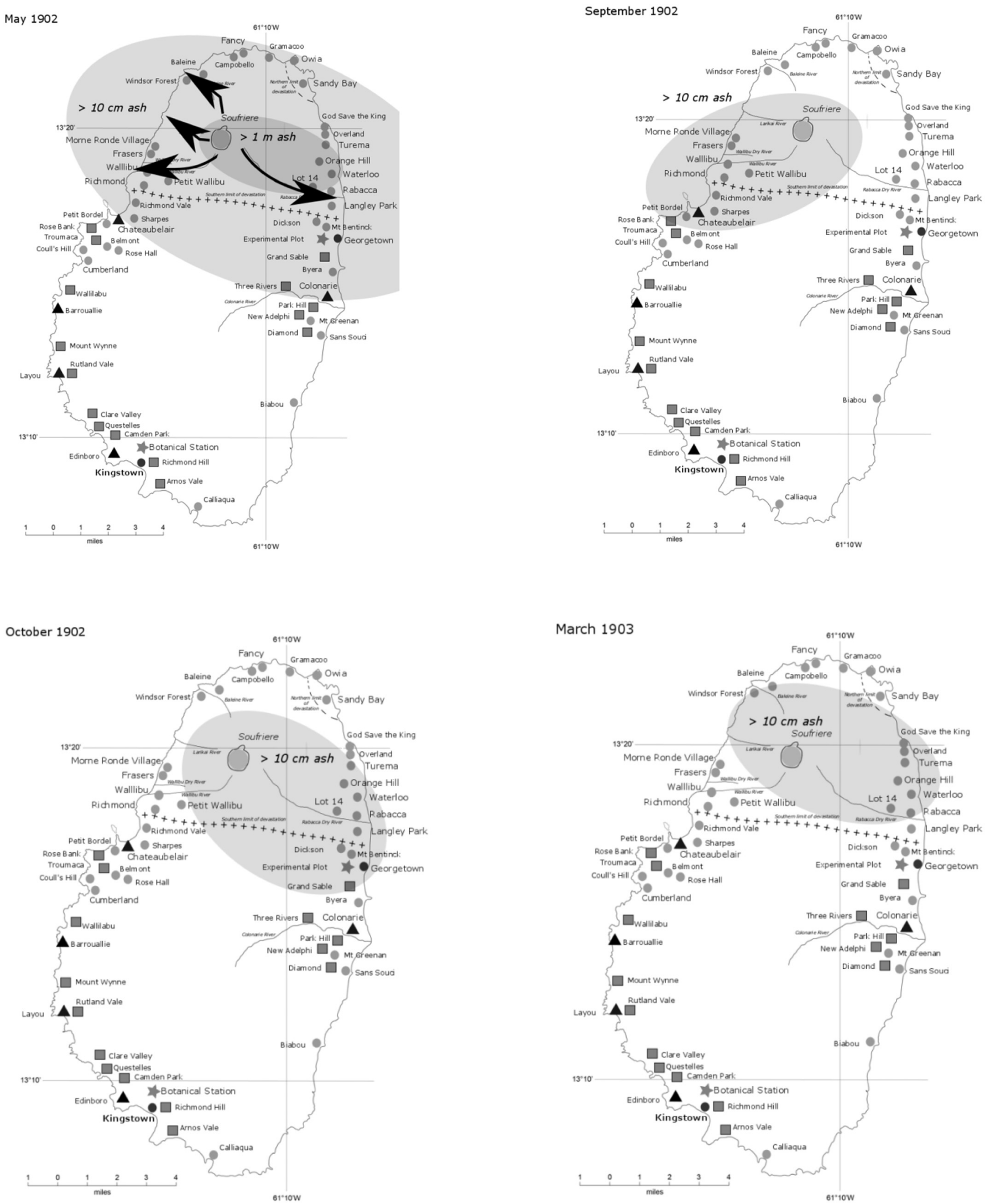

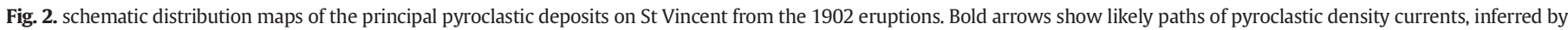

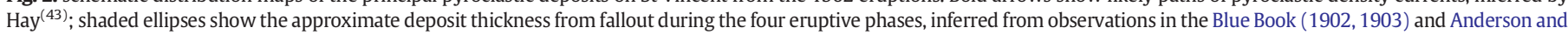
Flett (1903). 
of Chateaubelair which was also badly affected by the eruptions had either fled or taken refuge before the inundation by pyroclastic flows; and consequently casualties there were fewer.

Marquees and military hospital tents were quickly erected in the grounds of the hospital in Georgetown to cope with casualties. 221 people were treated for severe (191) and mild burns by the 20th June, of whom 79 died from their injuries (Blue Book, 1902). The temporary hospitals were removed by 3rd July 1902. Admissions to Hospital in the years 1902-1904 were the highest on record (901; Colonial Records, 1903a), although the rates of mortality and the patterns of disease were not notably different from the preceding years, with the exception of respiratory conditions. 93 deaths due to respiratory disease were recorded in the years 1904-1906, compared to only 35 in the years 1908-1910 (Colonial Reports, 1911). During the 1979 activity of the Soufrière, cases of asthmatic bronchitis showed a marked increase during the two weeks of explosive volcanic activity (Leus et al., 1981).

\section{Relief, recovery and lessons learned: a 'modern' disaster emergency?}

\subsection{Emergency relief}

At the time of the 1902 eruption St. Vincent's economy was in a critical state, and in the early stages of program to improve its long term prospects, following the collapse of the sugar industry and the 1898 hurricane (Colonial Reports, 1911). A disaster relief fund was set up in response to the eruption (Table 7), initially with a contribution of over $£ 50,000$ from the Lord Mayor of London's Mansion House Fund, augmented by donations from private individuals, concerned groups and Governments around the world, on a range of scales. By November 1902 , the Soufrière Eruption Fund had accumulated over $£ 70,000$, and eventually receipts totalled $£ 77,000$ (Blue Book, 1903, §126). A critical change in response from the earlier hazard events (the eruption of 1812 and the hurricane of 1831), was the view that this fund should be means to provide relief to those people suffering in the aftermath of eruption, rather than compensation to those landowners who experienced economic losses or needed to rebuild (See Table 3). Primary expenditure from the fund was directed at providing, first, emergency food, shelter and medical assistance; and later, for the purchase of materials for building. The patterns of reported expenditure over the period that the fund was active are shown in Fig. 3, along with a timeline of the status of the volcano, as deduced from the official records (Blue Book, 1902, 1903).

\subsection{Longer term responses and recovery}

A significant portion of the fund was eventually used to buy lands and rebuild roads in existing settlements (Fig. 3). However the governance of this fund was questioned from the early stages, and with the later eruptions the numbers of people needing to be permanently rehoused steadily increased, as more became uneasy about living in the north of the island (Table 5). On St Vincent, there was little agreement about how the considerable remaining funds could be spent, fuelled by perhaps a lack of trust in a Governor who had left the island immediately prior to the main eruption (Cox, 2004). Decision-making was slow, and only $£ 40,000$ of the $£ 77,000$ raised had been spent by May 1903. In June 1903 , Llewellyn returned $£ 33,000$ to London, on the understanding that $£ 25,000$ would be invested on the government's behalf (Fig. 3; Blue Book, 1903, §126, 128; Cox, 2004). The lack of funding released for rebuilding on the estate lands infuriated some landowners, but the Colonial Secretary in London held his ground (Table 5).

Among the most vocal complainants was Alexander Porter. He was the largest landowner at that time, and suffered damage to eight estates: one Leeward and seven Windward (Cox, 2004). Porter claimed losses of $£ 27,000$ (Table 5; Blue Book, 1903, §22, Sept 3, 1902), and cited 1813 as a precedent, when landowners were compensated after
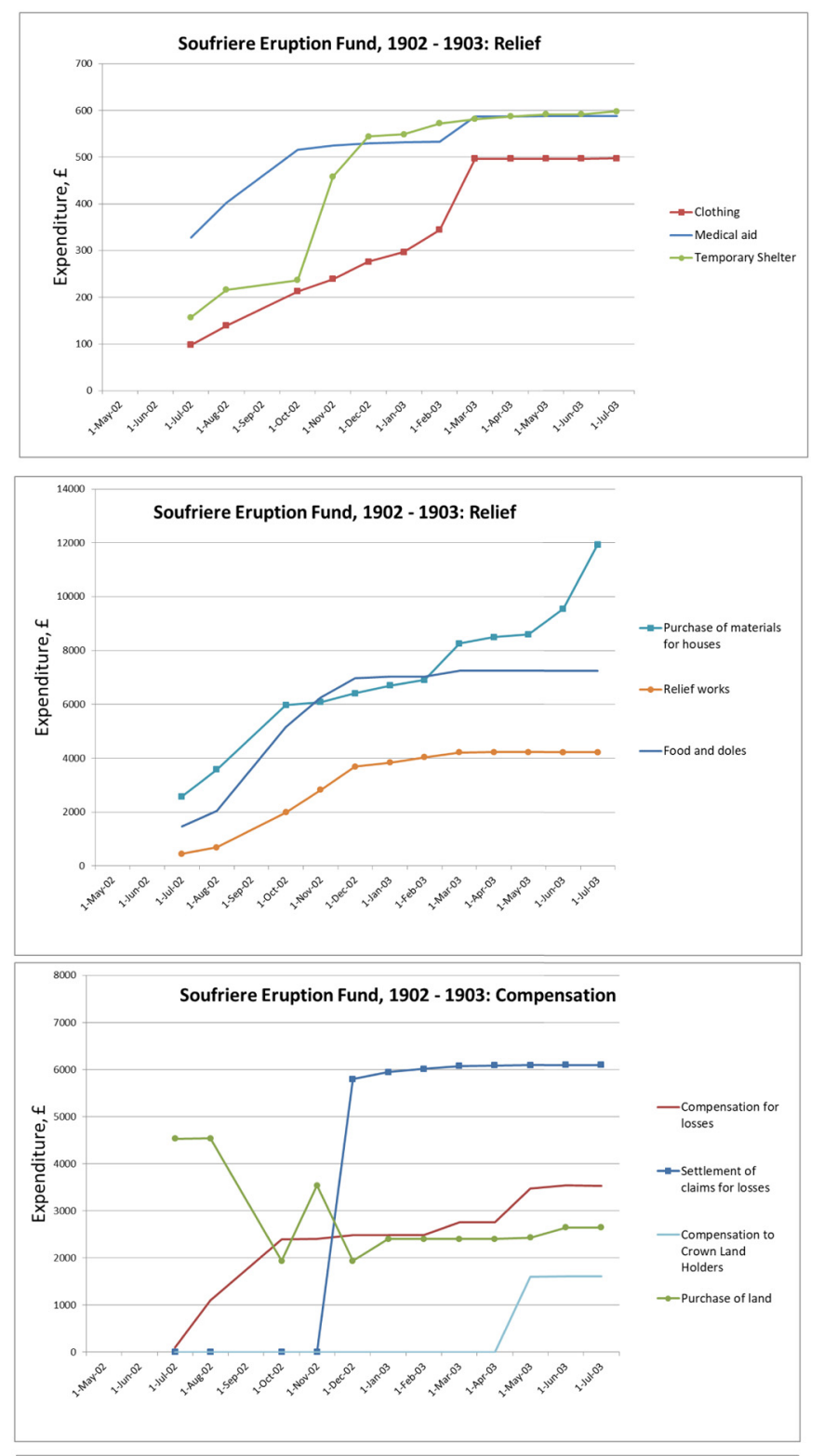

Volcano state: 1 steaming, 2 ash, 3 moderate eruption, 4 large eruption

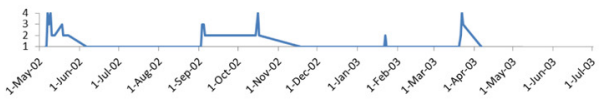

Fig. 3. Expenditure of the Soufrière Eruption Fund, reconstructed from monthly returns from July 1902 - July 1903 (Blue Book, 1903; Supplementary Table 2). (a) Relief reported expenditure on clothing, medical aid and temporary shelter. (b) Relief reported expenditure on new housing, repairs to roads, and doles and food. (c) Compensation - reported expenditure on claims for losses, and purchase of land. Sums reported under 'purchase of land...' in July and August 1902 were later offset by sales. (d) Schematic timeline of the state of the volcano, over the same period, from official records.

the 1812 eruption (Browne, 1813). He also argued that he had a special position, as a major employer and the owner of the canal system that supplied water to multiple estates, and that had been damaged during the eruption. Governor Llewellyn was inclined to find ways of compensating; indeed, he had compensated two other landowners and their families, but in the Colonial Office in London, Chamberlain remained 
firm: he could not assent to the use of the Relief Fund for 'making good losses' (Blue Book, 1903, §29). In December 1902, Captain Young concurred that 'Mr Porter is perfectly able, if he so wishes, .. to restore the canal', and proposed an alternative scheme for taking back ownership of the estates and the canal (Blue Book, 1903, §91; December 31, 1902). After Alexander Porter's death in 1903, his son, John, continued to lobby in the St Vincent Legislature and Parliament on the matter of the 'Carib Canal'. In March 1906 Winston Churchill, then Undersecretary of state for the Colonies, confirmed that the $£ 25,000$ was retained 'as a permanent investment'; the interest to be used for the 'cost of poor relief in St. Vincent' and the principal held as 'a special reserve to meet any possible recurrence of acute distress' (Hansard, 1906). Porter was eventually offered $£ 1600$ to fix the canal. In July 1909, Porter sold his lands to William Barnard of St Lucia (Hansard, 1906, 1908a, 1908b, 1908c; Cox, 2004).

The focus on immediate relief was not matched by long term investment in processes that would aid recovery, in part due to the imperative not to compensate individual landowners (even with infrastructural works) and difficulties in procuring alternative land (Table 5). The uncertainty introduced by the repeated explosions over the course of the year (Table 4; Fig. 3 ) also contributed to the lack of willingness to reinvest in the north of the island. Nonetheless the focus on the welfare of the communities and individuals impacted by the event does have some parallels with modern community-based disaster risk management. There is medical evidence that the provision of 'doles' benefitted malnourished islanders who might not otherwise have experienced this relief; and the number of reported criminal offences fell by $30 \%$ (from 1256 to 954 ) for the year 1902. Similarly, convictions dropped (from 719 to 529; Blue Book, 1902, 1903). However, the withdrawal of support, just 10 weeks after the initial eruption, for those deemed capable of finding paid work via emigration are not actions that would be supported today (these did meet with strong opposition at the time; Nanton, 1987).

As well as relief in the form of financial support (Table 6), neighbouring countries offered employment on schemes and in the form of food and plants. Employment schemes were largely to work as labourers on Estates in Dominica, Belize and Jamaica (Table 5), but there were also significant employment opportunities associated with the building of the Panama Canal. According to Cox (2004), while these inducements did not work but instead caused considerable resentment, nonetheless there was a clear increase in migration during the period between 1891 and 1911 (Spinelli, 1973; Gearing, 1988). This was perhaps associated more strongly with the pull of the economic opportunity rather than the push from those governing the island. There is also evidence for initiatives for immediate relief that met with some success: (i) the attempts to focus on agricultural production, improving diversity of crops; (ii) the wrapping of the recovery process into the longer term land re-distribution program; (iii) communications during the earlier stages of the eruption benefited from communication protocols designed to aid rapid reporting during hurricanes and tropical storms.

\subsection{Consequences for agriculture and the economy}

While there are meticulous records of economic crops and exports from Colonial records, it is harder to understand the impact of the eruptions on locally-grown and distributed provisions. However, some inferences can be gleaned from qualitative accounts, and from records of the distribution of crops from the Botanical Station (Table 8). Experience resulting from the 1898 Hurricane fed directly fed into the response to the volcanic eruptions, and experimentation in the agricultural station provided an impetus for innovations in practice and crop diversification. Powell and his team examined the effects of mixing volcanic ash with soil on different crops, and came up with practical ways to help smallholders continue to farm in areas affected by ash (Fig. 4). The Botanical Station also helped to distribute new plants (notably cacao, nutmegs
Table 8

Free plant distribution from the Botanical Station (1902-3).

\begin{tabular}{|c|c|c|c|c|}
\hline \multirow[t]{2}{*}{ Plant } & \multicolumn{2}{|c|}{$\begin{array}{l}\text { Plants distributed } \\
\text { under the Land } \\
\text { Settlement Scheme }\end{array}$} & \multicolumn{2}{|c|}{$\begin{array}{l}\text { Plants for refugees } \\
\text { at Clare Valley and } \\
\text { Camden Park }\end{array}$} \\
\hline & $1902 / 3$ & $1903 / 4$ & $1902 / 3$ & $1903 / 4$ \\
\hline Cacao & 234 & 4133 & 84 & 60 \\
\hline Arabian coffee & 44 & 724 & 201 & 60 \\
\hline Liberian coffee & - & 37 & & 12 \\
\hline Lime & - & - & 66 & - \\
\hline Nutmeg & 40 & 112 & - & 10 \\
\hline Cinnamon & 6 & 319 & 45 & 10 \\
\hline Black pepper & 6 & - & 22 & 5 \\
\hline Kola & 3 & - & 21 & 8 \\
\hline Banana suckers & 40 & - & - & - \\
\hline Bois immortel (shade for cacao) & 20 & - & - & - \\
\hline Rain tree & 3 & - & - & - \\
\hline Tomato & 6 & - & - & - \\
\hline Pine-apple suckers & - & 36 & 88 & - \\
\hline Black eye peas & - & - & $5 \mathrm{lbs}$ & - \\
\hline Cotton seed & - & $40 \mathrm{lbs}$ & - & - \\
\hline
\end{tabular}

and coffee), and encouraged diversification into new crops; notably sea island cotton. The Eruption Fund provided a grant of $£ 500$ in August 1903 (Blue Book, 1903, §130) for experimental cotton planting, which proved so successful that by 1910 cotton and cotton seed accounted for $42 \%$ of total exports, compared with arrowroot (30\%), and sugar and rum (6\%; Colonial Reports, 1912). Production from large sugar plantations, with outdated equipment and absentee owners, was in decline prior to the eruption, and this continued more steeply afterwards, as landowners responded to the lack of compensation for damage by selling their estates (Spinelli, 1973; Cox, 2004).

The process of redistributing land and of building new housing began soon after the first eruption - since some land had already been purchased following the Land Settlement Act. The process was further accelerated by the eruption, when additional estates - including

16. In many cases on exposed slopes where the wind and rain had produced full effect; the fine October "dust" was being gradually removed. I made several sections at the Experiment Station in Georgetown and elsewhere, and they all practically agree. The average thickness of the deposits was not znore than about nine inches. The sketch, below, shows the relative position and composition of the principal ]ayers.

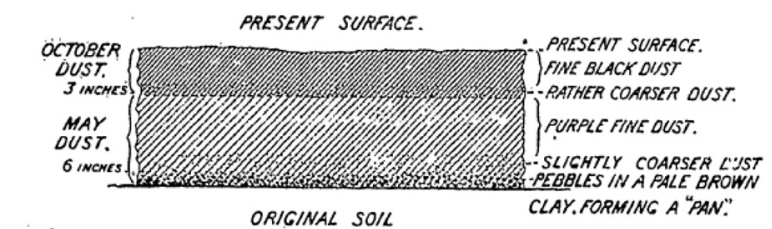

Section of volcanic deposits on the sugar and arrowroot estates in the Carib Country, Wind ward Const of St. Vincent.

20. My proposals in regard to starting cultivation on the estates in the Carib country, the details of which I have already discussed with some of the leading planters, suggest the treatment of the ash now on the land as follows :-

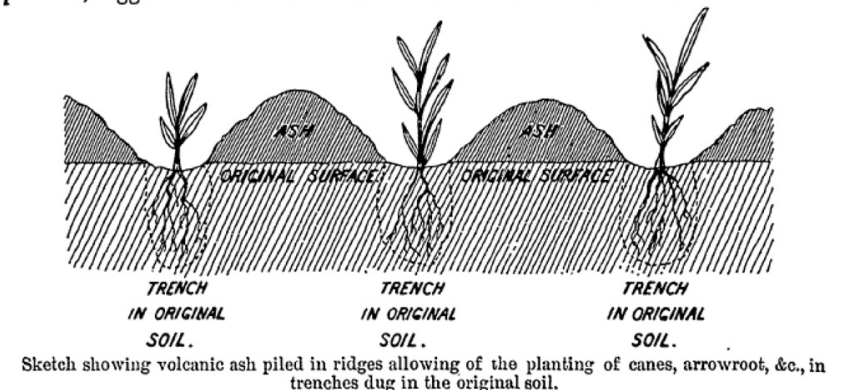

Fig. 4. Extract from the report of the Commissioner of Agriculture for the West Indies on experimentation relating to the addition of ash to soils in order to improve the efficiency of agriculture (Blue Book, 1903, §105). 
Camden Park and Rutland Vale - were purchased by the Eruption Fund to settle refugees (Colonial Reports, 1911). The residents of Morne Ronde did not feel well served in this process. Their lands at Morne Ronde, on the western flanks of the Soufrière, had been susceptible to landslides and flooding, and were badly hit by the 1898 hurricane, after which they had been offered lands at Rose Bank as a place to move their houses. This was unsatisfactory, as Rose Bank bay wasn't a good location for landing boats - which they needed to access their cultivated lands at Morne Ronde. When the May 7th eruption destroyed Morne Ronde, this left them with no other option but to move to Rose Bank; but now, to new houses that were inferior to those being built elsewhere (Table 6; Blue Book, 1903, §28, 112; Cox, 2004).

Meanwhile, the fate of the residents of Owia and Fancy, from the far north of St Vincent, was even more uncertain. Although both communities suffered in the eruption, with 56 people killed in Fancy, they were spared the wholesale destruction seen further south on the Windward side. The Governor vacillated over what to offer these communities. The new houses were intended only for those communities that had been destroyed in the eruption (Blue Book, 1903, §85, §92), which excluded Fancy and Owia. He eventually offered them the opportunity to emigrate, while refusing to buy any additional lands for resettlement (Table 5). After the eruption in late March 1903 which did affect Owia and Fancy, Llewellyn directed the administrator to 'erect as fast as possible as many temporary moveable huts as you can on rented land outside the danger zone' (Blue Book, 1903, §120, §124), to accommodate those newly displaced, or thought to be in danger. By April 1903, 156 families from all parts of the north of St Vincent remained unhoused ' 49 [families] in the Commissariat Building, the remainder scattering among friends or otherwise shifting for themselves', with a small number of refugees still living in Barracks at Layou, Barrouallie and Chateaubelair. Barracks built to house women and children refugees at Colonarie in October 1902, accommodated 601 people overnight after the March eruption (Blue Book, 1903, §77; §120). On May 22nd, 1903, Governor Llewellyn declared that 'Owia and Fancy are now abandoned' (Blue Book, 1903, §127), and, one month later 'I shall have sufficient funds in left the Colony to meet all present needs' (Blue Book 1903, $\S 128$ ). The needs of the refugee populations were not met, at least until after 1905, after which point all mention of their plight disappears from the colonial reports (Colonial Reports, 1911).

An interesting economic differential emerges between the arrowroot crop and the sugar crop. Following the passage of the 1898 hurricane the price of sugar responded to the region-wide impacts of the Hurricane (Barbados was more strongly impacted than St. Vincent for example). However prices of sugar did not rise in response to the very localized impacts of the 1902, eruption. In contrast, the response of the arrowroot market to the eruption was quite different. In the late 19th Century St. Vincent dominated the market, and he price of arrowroot doubled overnight in London following the eruption. Thus the economic response to agricultural stress may help to improve the recovery process: higher prices for the crops that remain would undoubtedly be an advantage if the population at large (rather than individual landowners) were able to benefit from this effect.

\section{Learning from the past: lessons for future eruptions}

One of the most important lessons from this analysis is that there are strong signs that the large eruption had significant precursory signs in the weeks and months leading up to the eruption, including circumstantial evidence for small explosive events producing a light scattering of ash close to the volcano, and felt volcanic earthquakes. These would certainly be recognized through modern monitoring methods, in advance of a future eruption; as in 1979, for example (c.f. Shepherd et al., 1979).

'My grandfather was born in the 1800s and he told us that for days they were going to the mountains and seeing this white thing on the plants and so on. But nobody knew exactly what it was. A lot of people were living in the Morne Ronde and the Wallilabou areas. When it erupted it caught a lot of people by surprise so only few people were able to get out and others died. What happened was that there were signs, but because the volcano was not studied as much as it is today. The older people did not know what it was.'

[[Male interviewee, Petit Bordel, 2014]]

There was a pronounced asymmetry in the loss of life across the island during the climactic 7th of May eruption despite a less pronounced asymmetry in the physical impacts of the eruption. This has been attributed to the more ambiguous signs of unrest seen in the east of the island; but could be explained by the working conditions in the large Estates on the east of the island. Autonomous decisions to leave the Estates once the daily routine had started were perhaps harder to make. There is no account of management decisions being made that would allow workers to leave earlier in the morning on the Windward side of the volcano. Reports suggest the population was scattered at the time, with those people out in the open having few options available for shelter on a short time-scale. This underlines a need for the communication of warnings and messages that are pertinent to the working circumstances and capacity for decision-making of the intended recipients, as well as sensitive to the time-scales over which it is possible to evacuate the population.

The additional strain placed by the extended period of unrest through the sequence of explosive eruptions that lasted until March 1903 (Tables 4, 5; Fig. 3) also provides a useful demonstration of the impacts of long-lived volcanic eruptions on small island economies. Recovery from the initial shock was severely impacted by these subsequent events, and exacerbated by weak governance or poor decisionmaking. This illustrates how long term views of hazards such as volcanic eruptions are vital in disaster planning, so that policy, risk management and populations are prepared for repeated shocks. One of the lessons that we infer from analysis of the official accounts is that some elements of the response of the Colonial Government to the crisis were faster than they might otherwise have been. The land reform process that had begun with the collapse of the sugar industry, and then the hurricane, meant that when the volcano erupted in May 1902 there were already areas set aside for new settlements; so the building of houses on these plots, and rehousing of families from some of the villages that had been destroyed, was able to start quickly. It is also clear that the land reform soon slowed, as the Governor first got bogged down in the process of trying to buy damaged estates to compensate their owners - which would not immediately yield lands sufficiently safe for resettlement; and then abandoned the idea of purchasing any further land, preferring to negotiate rentals. The final refugees weren't settled until late in 1905, and no new lands were purchased until 1911 (Colonial Reports, 1911, 1915), when an estate at Sandy Bay was bought for the resettlement of families from Camden Park and Clare Valley.

The economic impacts of volcanic eruptions can be devastating to small island economies, and they have the peculiar distinction compared to hydro-meteorological phenomena of being confined to that particular island, thus market forces respond in a relatively unique way. In the case of the 1902 eruption, a commodity almost unique to the island doubled in value overnight (arrowroot) while that found elsewhere (sugar) retained a stable price. However, the shock to the ailing sugar cane industry gave a fresh impetus to the development of the sea cotton and cocoa industries; while the admixture of fresh volcanic ash with the previously cultivated soils provided a temporary source of additional nutrients (Fig. 4). To date, there are few studies that analyse the economic effects of volcanic eruptions but this evidence suggests that understanding market response to commodities (usually crops and livestock) impacted locally by activity could provide valuable insights into how to direct future relief and re-growth efforts.

The close association of the 1898 hurricane with the 1902 eruption is a graphic demonstration of the repeated shocks that many small island 
developing states suffer, arising from multiple hazardous processes. The island's population was still recovering from the social and economic impacts of the hurricane, against a backdrop of high levels of poverty, as a consequence of a long term lack of investment from absentee landowners. Our analysis of official records demonstrate that those disadvantaged workers on the northern estates of St. Vincent were also disproportionately impacted by the eruption, becoming reliant on support for food and accommodation. Ultimately the period between the census of 1891 and 1911 saw a net migration of 33,000 people; a high proportion of the population compared to the 1911 census population of 47,916 (Spinelli, 1973). For many citizens recovery from these hazards involved migration. The evidence from these eruptions is that the shock of the event tended to exaggerate or accelerate social or economic processes already in motion. In this instance, the decline of the sugar industry was accelerated and the sale and re-distribution of land was increased. This analysis provides further evidence that these accelerations can provide positive as well as negative benefits to the long term recovery process.

In this instance the eruption contributed to improved success with the re-distribution of land holdings envisaged by the creation of the 'Land Settlement Act'. Existing landowners became more willing to sell their land, and necessity perhaps overcame the initial suspicions that potential beneficiaries had for the terms of the scheme. Nonetheless, there is some evidence that some of these new land holdings were only temporary and households 'drifted back to their original plots where the soil had been enriched over time by the heavy ashfall' (personal communication reported in Nanton, 1987; p.182). There is evidence that some learning from the recovery processes associated with the hurricane benefitted responses to the eruption. In particular, the rapid experimentation (Fig. 4) and distribution of plants to the small market garden holders and distribution of allotments had a positive impact on the long-term recovery from the eruption.

The window for learning political and crisis-management lessons from these types of events is demonstrably short: the political memory of the importance of preparing for and expecting volcanic eruptions had faded by 1910 (Cox, 2004). The residual $£ 25,000$ from the Soufrière Relief Fund, which had been sent to the UK for investment for the relief of future disasters, was no longer available for rebuilding of critical infrastructure after 1906; and disappeared from political view after 1908. Land reform policies stuttered (Nanton, 1983; John, 2006), and political and socio-economic changes meant that by the time of the next major eruption of St Vincent, the agricultural economy was dominated by the production of bananas for export. Ash from the explosive eruptions in April 1979 caused extensive damage to that year's crop (Robertson, 1995); damages that were exacerbated during the next year by both drought, and the arrival of hurricane Allen in August 1980 (Grossman, 1998).

\section{Conclusions}

Historical analysis of the careful records from events even $>100$ years ago can provide insights into disaster risk reduction today. This analysis demonstrates that the devastating immediate effects of explosive volcanic eruptions can be mitigated by responses and actions in the face of their occurrence. In the case of the 1902-03 eruptions of Soufrière St. Vincent, the long term impacts were complex. Those who were able to act on the early visible signs of eruption saved their lives by moving. The repeated explosions through late 1902 and 1903 hampered relief and recovery efforts and prompted further population movement (both internal and external displacements). Nonetheless the evidence suggests that the integration of relief efforts from the volcano with an ongoing program of development at the time improved the effectiveness of the response, at least in the short term. Analysis of the measurable economic effects of the 1902-1903 eruptions of the Soufrière of St Vincent suggest that it acted to accelerate the decline of the sugar industry on St. Vincent, but that recovery in other commodities occurred within one or two years.
The detailed analysis of the impacts of the eruption also points out the value of relatively small measures (e.g. the rapid growth and provision of plug plants) in enabling populations to adapt and cope with the environmental shock. However, no strong evidence was found for a substantive long-term change in the framing of disaster risk preparedness by either the local population or policymakers, even in the light of two intense high impact events such as the 1898 hurricane rapidly followed by the 1902 eruption of St. Vincent.

Explosive volcanic eruptions on St Vincent have occurred repeatedly. Each time, ash fallout and pyroclastic density currents have affected broad swathes of the northern half of St Vincent, causing damage to crops, livestock and infrastructure, and the death and displacement of large numbers of people, notably in 1902. One legacy of the 1902-3 eruptions were the oral histories of this eruption, which probably had a significant impact on the rapid response - and selfevacuation - of the affected communities to eruptions of April 1979 (e.g. Robertson, 1995). Although patterns of production have changed significantly, the patterns of settlement on St Vincent are not qualitatively very different from those in 1902, or 1979; and many communities on the northern leeward and windward sides of the island remain at risk both from the hazards of living on the flanks of a steep-sided tropical island; as well as being within reach of an active volcano.

Supplementary data to this article can be found online at https://doi. org/10.1016/j.jvolgeores.2018.03.005.

\section{Acknowledgements}

We thank librarians and archivists at the British Library, the Royal Commonwealth Society and Cambridge University Library, the University of Oxford's Bodleian Libraries, the St Vincent and the Grenadines National Archives, the Barbados Museum and Historical Society, the Natural History Museum, London, and the British Geological Survey for facilitating access to their collections. We acknowledge the very helpful support of many people and agencies on St Vincent, and of our collaborators across and beyond the STREVA project, and, in particular, Professor Richie Robertson, UWI Seismic Research Centre and Dr Paul Cole, University of Plymouth, for discussions. We also thank Jim Gardner and two reviewers for their efficient handling of the paper. This work was supported by the UK Natural Environment Research Council (NERC) and Economic and Social Research Council (ESRC) through the Increasing Resilience to Natural Hazards programme [STREVA project, Grant numbers NE/J020001/1, NE/J020052/1], NERC IOF grant NE/ M017621/1, and NERC and AHRC Global Challenges Research Fund grants NE/P016014/1 and AH/P007600/1.

\section{References}

Adams, E., 2002. People on the Move: The Effects of Some Important Historical Events on the People of St. Vincent and the Grenadines. R \& M Adams Book Centre, Kingstown, St. Vincent and the Grenadines.

Anderson, A., 1785. An account of Morne Garou, a mountain in the island of St Vincent with a description of the volcano on its summit. Phil. Trans. R. Soc. London 75, 16-31.

Anderson, T., 1908. Report of the eruptions of the Soufrière in St Vincent in 1902, and on a visit to Montagne Pelee in Martinique. Part II - the changes in the districts and the subsequent history of the volcanoes. Philos. Trans. R. Soc. Lond. A 208, 275-303.

Anderson, T., Flett, J.S., 1903. Report on the eruptions of the Soufrière, in St Vincent, in 1902 and on a visit to Montagne Pelee in Martinique, part I. Philos. Trans. R. Soc. Lond. A 200, 353-553.

Arculus, R.J., Wills, K.J.A., 1980. The petrology of plutonic blocks and inclusions from the Lesser Antilles island arc. J. Petrol. 21, 743-799.

Armijos, M.T., Few, R., 2016. Vulnerability to volcanic risk and multiple hazards in the island of St. Vincent. DEV Reports and Policy Papers Series. School of International Development, University of East Anglia, UK

Barclay, J., Haynes, K., Mitchell, T., Solana, C. Teeuw, R., Darnell, A., Crosweller, S., Cole, P. Pyle, D., Lowe, C., Fearnley, C., Kelman, I., 2008. Framing volcanic risk communication within disaster risk reduction: finding ways for the social and physical sciences to work together. In: Liverman, D.G., Pereira, C.P.G., Marker, B. (Eds.), Communicating Environmental Geoscience. 305. Geol. Soc., London, Spec. Pub., pp. 163-177.

Barclay, J., Haynes, K., Houghton, B., Johnston, D., 2015. Social processes and volcanic risk reduction. In: Sigurdsson, $\mathrm{H}$. et al. (Ed.), The Encyclopedia of Volcanoes, pp. 1203-1214. 
Blue Book, 1899a. West Indies. Correspondence Relating to the Hurricane on 10th-12th September, 1898, and the Relief of Distress Caused Thereby: Parliamentary Paper by Command, Cd. 9205. HMSO, London.

Blue Book, 1899b. West Indies. Further Correspondence Relating to the Hurricane on 10th-12th September, 1898, and the Relief of Distress Caused Thereby. Parliamentary Paper by Command, Cd. 9550. HMSO, London.

Blue Book, 1902. Correspondence Relating to the Volcanic Eruptions in St Vincent and Martinique in May 1902, With Map and Appendix: Parliamentary Paper by Command, Cd. 1201. HMSO, London.

Blue Book, 1903. Further Correspondence Relating to the Volcanic Eruptions in St Vincent and Martinique in 1902 and 1903: Parliamentary Paper by Command, Cd. 1783. HMSO, London.

Boa, S., 2001. Experiences of women estate workers during the apprenticeship period in St Vincent, 1834-38: the transition from slavery to freedom. Women's Hist. Rev. 10:381-408. https://doi.org/10.1080/09612020100200291.

Boruff, B.J., 2006. Historic hazards events for St Vincent and the Grenadines. 13 pp. www. islandvulnerability.org/SVGEventsBoruff.doc (Accessed November 7, 2017).

Boruff, B.J., Cutter, S.L., 2007. The environmental vulnerability of Caribbean island nations. Geogr. Rev. 97, 24-45.

Browne, A., 1813. Select Committee on Petition of Proprietors of Estates in Island of St. Vincent, Report (Eruption of Mount Souffrier). 182. House of Commons Papers, London (14 pp).

Byres, J., 1777. References to the Plan of the Island of St Vincent as Surveyed from the Year 1765 to 1773 . Hooper, Ludgate Hill.

Colonial Reports, 1901. Annual, No 312, St Vincent: Report for 1899, Cd. 431. HMSO, London.

Colonial Reports, 1903a. Annual, No 403, St Vincent: Report for 1902-3, Cd. 1768. HMSO, London.

Colonial Reports, 1903b. Annual, No 385, St Vincent: Report for 1901, Cd. 1388. HMSO London.

Colonial Reports, 1911. Miscellaneous, No 77, St Vincent: Report on the Administration of the Roads and Land Settlement Fund, Cd. 5742. HMSO, London.

Colonial Reports, 1912. Annual, No. 712, St Vincent: Report for 1910-11, Cd. 6007. HMSO London.

Colonial Reports, 1915. Miscellaneous, No 90, St Vincent: Report on the Administration of the Roads and Land Settlement Fund, Cd. 7876. HMSO, London.

Cox, E.L., 2004. Eruption du volcan de la Soufrière a Saint-Vincent, le 7 mai 1902. In: Ursulet, Léo (Ed.), Saint-Pierre: Mythes et réalités de la cite créole disparaue, Ibis Rougue Editions, pp. 33-54.

Curtis, G.C., 1902. Looking into the Caribbean craters. Cent. Mag. 65 (December), 420-434.

Dawson, G., Lintott, C., Shuttleworth, S., 2015. Constructing scientific communities: citizen science in the nineteenth and twenty-first centuries. J. Vic. Cult. 20, 246-254.

Defoe, D., 1718a. An account of the island of St Vincent in the West Indies and of its entire destruction on the 26th March last, with some rational suggestions concerning the causes and manner of it. Mist's Wkly. J. July 5 (Issue 82).

Defoe, D., 1718b. addendum ('Pirates.. of the West Indies .. pretend to tell .. that the island .. is turn'd into a Vulcano'). Mists Wkly. J. August 2nd (Issue 86).

Foster Huggins, P., 1902. Report on the Soufrière. B.W.I., Saint Vincent (30 pp).

FRA, 2010. Global Forest Resources Assessment: Saint Vincent and the Grenadines: FAO Report FRA2010/181, Rome. http://www.fao.org/docrep/013/al616E/al616E.pdf, Accessed date: 7 November 2017

Gearing, M.J., 1988. The Reproduction of Labor in a Migration Society: Gender, Kinship and Household in St Vincent, West Indies. PhD thesis. University of Florida $454 \mathrm{pp}$. http://ufdc.ufl.edu/AA00024794.

Grossman, L.S., 1998. The Political Ecology of Bananas. University of North Carolina Press $292 \mathrm{pp}$.

Hansard, 1906. The Souffriere Disaster: HC Deb 13th March, 1906. vol. 153 col. 1094

Hansard, 1908a. St Vincent Relief Fund: HC Deb 9 July 1908. vol. 192 col. 60-61.

Hansard, 1908b. Carib Canal - St Vincent Eruption Fund: HC Deb 15 July 1908. vol. 192 col. 844-845.

Hansard, 1908c. St. Vincent Eruption Relief Fund: HC Deb 28th July 1908. vol. 193 col. 1221-2.

Hay, R.L., 1959. Formation of the crystal-rich glowing avalanche deposits of St Vincent BWI. J. Geol. 67, 540-562.

Heath, E., MacDonald, R., Belkin, H., Hawkesworth, C., Sigurdsson, H., 1998. Magma genesis at Soufrière Volcano, St Vincent, Lesser Antilles Arc. J. Petrol. 39, 1721-1764.

Hicks, A., Armijos, M.T., Barclay, J., Stone, J., Robertson, R., Cortes, G.P., 2017. Risk communication films: process, product and potential for improving preparedness and behaviour change. Int. J. Disaster Risk Reduct. 23:138-15. https://doi.org/10.1016/j. ijdrr.2017.04.015.

Hovey, E.O., 1902. Martinique and St. Vincent: a preliminary report upon the eruptions of 1902. Am. Mus. Nat. Hist. Bull. 16, 333-372.
Howard, R.A., 1954. A history of the Botanic Garden of St Vincent, British West Indies. Geogr. Rev. 44, 381-393.

John, K., 2006. Land Reform in Small Island Developing States: A Case Study on St. Vincent, West Indies 1890-2000. Virtualbookworm.com.

Lacroix, A., 1904. La Montagne Pelée et ses éruptions. Masson et cie, Paris (662pp).

Leus, X., Kintanar, C., Bowman, V., 1981. Asthmatic bronchitis associated with a volcanic eruption in St Vincent, West Indies. Disasters 5, 67-69.

Macdonald, R., Hawkesworth, C.J., Heath, E., 2000. The Lesser Antilles Volcanic Chain: a study in arc magmatism. Earth Sci. Rev. 49, 1-76.

Mani, L., Cole, P.D., Stewart, I., 2016. Using video games for volcanic hazard education and communication: an assessment of the method and preliminary results. Nat. Hazards Earth Syst. Sci. 16:1673-1689. https://doi.org/10.5194/nhess-16-1673-2016.

Melekhova, E., Blundy, J., Robertson, R., Humphreys, M.C.S., 2015. Experimental evidence for polybaric differentiation of primitive arc basalt beneath St. Vincent, Lesser Antilles. J. Petrol. 56:161-192. https://doi.org/10.1093/petrology/egu074.

Musgrave, T.B.C., 1891. Historical and Descriptive Sketch of the Colony of St Vincent, W.I. Gardner's, Jamaica (26 pp).

Nanton, P.W., 1983. The changing pattern of state control in St Vincent and the Grenadines. In: Ambursley, F., Cohen, R. (Eds.), Crisis in the Caribbean. Heinemann, London, pp. 223-246.

Nanton, P.W., 1987. The Transfer of Power in a Small Caribbean Country: The Role of the State in St. Vincent and the Grenadines. PhD Thesis. University of Sussex 339 pp., uk. bl.ethos.377073.

Nanton, P., 2017. Frontiers of the Caribbean. Manchester University Press (168 pp).

Page, J., 1902. Reports of vessels as to the range of volcanic dust. National Geographic Magazine. 13, pp. 299-301.

Pichavant, M., Mysen, B.O., Macdonald, R., 2002. Source and $\mathrm{H}_{2} \mathrm{O}$ content of high-MgO magmas in island arc settings: an experimental study of a primitive calc-alkaline basalt from St Vincent, Lesser Antilles arc. Geochim. Cosmochim. Acta 66, 2193-2209.

Powell, H., 1898. The Windward Islands hurricane of September 10-11, 1898. Mon. Weather Rev. 26, 393-394

Powell, H., 1900. Distribution of economic plants in the island of St Vincent after the hurricane of September 1898. West Indies Bull. 1, 285-288.

Pyle, D.M., 2017. Volcanoes: Encounters through the Ages. Bodleian Publishing (224pp).

Pyle, D.M., 2018. What can we learn from records of past eruptions to better prepare for the future? In: Fearnley, C., Bird, D., Jolly, G., Haynes, K., McGuire, B. (Eds.), Observing the Volcano World, Advances in Volcanology. Springer, Berlin, Heidelberg https:// doi.org/10.1007/11157_2017_5 (in press)

Richardson, B.C., 1997. Economy and Environment in the Caribbean: Barbados and the Windwards in the Late 1800s. The Press, University of the West Indies (294pp).

Robertson, R.E.A., 1995. An assessment of the risk from future eruptions of the Soufrière volcano of St Vincent, West Indies. Nat. Hazards 11, 163-191.

Robson, G.R., Tomblin, J.F., 1966. Catalogue of the Active Volcanoes of the World Including Solfataric Fields. Part XX West Indies, International Association of Volcanology, Rome.

Roobol, M.J., Smith, A.L., 1975. A comparison of the recent eruptions of Mt Pelee, Martinique, and Soufrière, St Vincent. Bull. Volcanol. 39, 214-240.

Royal Commission, 1897. Report of the West India Royal Commission, C. 8655. HMSO, London.

Russell, I.C., 1902a. Phases of West Indian eruptions. Cent. Mag. 64 (September), 786-800.

Russell, I.C., 1902b. The recent volcanic eruptions in the West Indies. National Geographic Magazine. 13, pp. 267-285.

Shepherd, C., 1831. An Historical Account of the Island of Saint Vincent. Nicol, London (216pp).

Shepherd, J.B., Aspinall, W.P., Rowley, K.C., Pereira, J., Sigurdsson, H., Fiske, R.S., Tomblin, J.F., 1979. The eruption of Soufrière volcano, St Vincent, April-June 1979. Nature 282, 24-28.

Smith, S.D., 2011. Volcanic hazard in a slave society: the 1812 eruption of Mount Soufrière in St Vincent. J. Hist. Geogr. 37, 55-67.

Smith, S.D., 2012. Storm hazard and slavery: the impact of the 1831 great Caribbean hurricane on St Vincent. Environ. Hist. 18, 97-123.

Spinelli, J., 1973. Land-use and Population in St Vincent, 1763-1960. PhD thesis. University of Florida 428 pp. http://ufdc.ufl.edu/UF00098940/.

Wadge, G., Robertson, R.E.A., Voight, B. (Eds.), 2014. The Eruption of Soufrière Hills Volcano, Montserrat, from 2000-2014. Mem. Geol. Soc. London 39501 pp.

Wilkinson, E., Lovell, E., Carby, B., Barclay, J., Robertson, R.E.A., 2016. The dilemmas of risksensitive development on a small volcanic island. Resources 5:21. https://doi.org/ 10.3390/resources5020021.

Zellmer, G.F., Annen, C., Charlier, B.L.A., George, R.M.M., Turner, S.P., Hawkesworth, C.J., 2005. Magma evolution and ascent at volcanic arcs: constraining petrogenetic processes through rates and chronologies. J. Volcanol. Geotherm. Res. 140, 171-191. 